\author{
Marek REMBIERZ \\ Uniwersytet Śląski w Katowicach \\ marek.rembierz@gmail.com
}

\title{
UCZENIE SIĘ PLURALIZMU I KSZTAŁTOWANIE TOŻSAMOŚCI RELIGIJNEJ W KONTEKŚCIE KULTUROWYCH I ŚWIATOPOGLĄDOWYCH ODMIENNOŚCI - MIĘDZY TRADYCYJNYM ZRÓŻNICOWANIEM A WSPÓŁCZESNYM PLURALIZMEM $^{1}$
}

ABSTRACT Learning pluralism and shaping religious identity in the context of cultural and ideological differences - between traditional diversification and contemporary pluralism

In the public and academic discourse, pluralism is recognized as one of the main features of the contemporary Western world, which is culturally, religiously and ideologically diversified. According to its supporters and promotors, pluralism is a significant value which constitutes a virtue of the modern world. However, pluralism is also associated with various problems, dilemmas and difficulties.

Contemporary cultural pluralism has a substantial impact on shaping the religious identity and causes significant changes within it. In the 1970s and 1980s, sociologists indicated some pluralization processes which modified religious identity. In 1983, while examining the determinants of the Church activities in the industrial society, Janusz Mariański - a sociologist of religion, agreed with the observation that "what is eliminated in the pluralistic society is the situation of the

\footnotetext{
Tekst powstał w ramach projektu: „Miejsce religii w sferze publicznej. Tożsamości religijne w wieloreligijnych regionach Europy Środkowo-Wschodniej na przykładzie wybranych regionów Polski, Ukrainy i Słowacji", konkurs OPUS, ID 222126, nr rej. 2013/09/B/HS6/0307. Uwzględniając wskazany w projekcie badawczym kontekst słowacki, w tekście przywołuję także słowackie teksty, zachowując w niektórych fragmentach język słowacki, w dużej mierze zrozumiały dla polskiego czytelnika, gdyż oryginalne brzmienie lepiej oddaje sens i „tembr” przywoływanych wypowiedzi.
} 
monopoly of church institutions in interpreting human reality in the consciousness of the contemporary man. Religious values are not the only which give sense to fundamental values institutionalized in the society". Thus, religion ceases to have the earlier potentialities of the monopoly in the sphere of fundamental values.

The issue of pluralism, widely discussed today and raising a lot of dispute, can be viewed from the perspective of the analysis of broadly understood learning processes and outcomes (the analysis of educational and self-educational activities). Pluralism can be perceived as a process and a result of mutual and constant learning in the (educationally potent and dynamic) relationship with individuals who show more or less different attitudes and beliefs - a process of learning those who, by entering relationships with each other, preserve and at the same time shape their different identities. If a person enhances the inner will to learn constantly, to multiply the cognitively valuable knowledge, to improve intellectual skills, this willingness should lead to the recognition of important intrinsic and educational values of other attitudes and beliefs. By meeting what is to some extent different, it is possible to learn further and, with growing accuracy, to recognize the fields of one's own ignorance.

Modern pluralism poses serious challenges to religion. The statement used in sociological discourse that "pluralistic tendencies are destructive to religion" can be read by those for whom religion - confessing religious faith - is close and important as a challenge to oppose pluralism for the sake of the defense of traditionally perceived religious faith, the defense of its world view and its institution. Such a deeply engaged interpretation imposes formulating an alternative: either the pluralistic tendencies which are destructive to religion get intensified or religion gets more power, counteracting the dangerous tendencies of pluralism which pose threat to religion. Two different ways of the inner diagnosis of religion are outlined here. The first is a fundamentalist one and consists in "strengthening its own positions", as it recognizes that the overemphasized (in religion) elements of openness and dialogue weaken religion from inside, making it more sensitive to destructive influence of pluralism (openness and dialogue are a "Trojan horse" of hostile pluralism, let into the inside of religion). The second way, of the in-depth and self-critical reflection upon the current situation of religion, may lead to recognizing (among the elements so far belonging to religious identity) those which - in the context of pluralism and in spite of their presence for many centuries - are of doubtful value or even become the causes of the destructive crisis of religion in spite of their being situated inside it. Therefore, the situation of pluralism allows for cleaning religion, which is confronted with pluralism and was earlier closed within its homogeneous world. At the same time, the religious crisis in the pluralistic world can be viewed as a crisis of inner maturation and growth of religion.

Undertaking ideological discussion with the conviction that common and binding arrangements should be reached is not an easy matter. What is more, in the opinion of people who believe in the necessity of confrontation, this discussion is not even needed. It can be assumed that, in the diversified social life, the persistent con- 
ducting of difficult negotiations is indispensable, instead of the state of embittered confrontation. Referring to the standpoint of Jerzy Nikitorowicz, who promotes learning pluralism and intercultural dialogue, the dialogical concept of pluralism can be applied: "In the pluralistic society, the process is taking place of reaching commonly shared values by individuals and groups through unceasing negotiations of values and interests, the process of shaping the sensitivity to others and the need for mutual respect and recognition, without the division to upper and lower cultures".

Keywords: pluralism, learning pluralism, religion, identity, education

Słowa kluczowe: pluralizm, uczenie się pluralizmu, religia, tożsamość, edukacja

[...] gdy moge uczyć się od ciebie i chce uczyć się w interesie poszukiwania prawdy, wówczas musze ciebie nie tylko tolerować, lecz także uznać za potencjalnie równoprawnego.

Karl Raimund Popper ${ }^{2}$

Pluralizm burzy dawny oczywisty „świat wiedzy” [...] „mój” system sensu nie jest oczywisty dla innych [...]. Jednostka wciąż musi stawiać sobie pytanie, czy nie powinna w inny sposób ksztattować swojego życia.

Janusz Mariański ${ }^{3}$

W spoteczeństwie pluralistycznym ma miejsce proces dochodzenia [...] do wspólnych wartości na drodze nieustannych negocjacji [...], ksztattowania się wrażliwości na innych $i[\ldots]$ wzajemnego szacunku.

Jerzy Nikitorowicz ${ }^{4}$

\section{WPROWADZENIE}

Za jedną z kluczowych kategorii współczesnej kultury i życia społecznego - w kręgu cywilizacji zachodniej - dość powszechnie uznaje się pluralizm5. Funkcjonują jednak

2 K.R. Popper, Tolerancja i intelektualna odpowiedzialność (skradzione od Ksenofanesa $i$ Woltera), [w:] tenże, W poszukiwaniu lepszego świata. Wyktady i rozprawy z trzydziestu lat, przeł. A. Malinowski, Warszawa 1997, s. 243.

3 J. Mariański, Religia w spoteczeństwie ponowoczesnym. Studium socjologiczne, Warszawa 2010, s. 28.

4 J. Nikitorowicz, Od podmiotowości do międzykulturowości i z powrotem. Próba interpretacji niektórych perspektyw teoretycznych, [w:] W poszukiwaniu teorii przydatnych $w$ badaniach międzykulturowych, red. T. Lewowicki, E. Ogrodzka-Mazur, Cieszyn 2001, s. 18.

5 W socjologicznym oglądzie przemian współczesnej kultury przejawiający się w niej pluralizm częstokroć wysuwa się na plan pierwszy: Pluralizm radykalny, tolerancyjny wobec sprzecznych wartości i norm, 
mniej lub bardziej odmienne, a nawet niesprowadzalne do siebie sposoby rozumienia i oceniania pluralizmu jako idei, jako wartości i jako faktu 6 . Opinie dotyczące tego, czym jest i czym - w ujęciu normatywnym - powinien być współcześnie pluralizm oraz jaką przypisuje się mu wartość, mogą być - ze względu na różniące się przekonania aksjologiczne, tradycje intelektualne i doświadczenia kulturowe - zdecydowanie rozbieżne. Te nasilające się różnice w rozumieniu pluralizmu dochodzą do głosu zwłaszcza wtedy, gdy rozpatruje się kształtowanie i przemiany tożsamości religijnej w kontekście wzmożonego występowania kulturowych i światopoglądowych odmienności. Zaświadcza o tym także polska (i podobnie słowacka) debata o pluralizmie społecznym i kulturowym, w której - choć jest ona częścią globalnej dyskusji o transformacjach życia społecznego i jego pluralistycznych postaciach - występują momenty dla niej swoiste, uwarunkowane odrębnością własnych i środkowoeuropejskich doświadczeń historycznych.

Trudności pojęciowe wzmaga zespolenie kwestii pluralizmu z kwestią religii, która niesie z sobą swój bagaż kłopotów pojęciowych i sporów ideowych. Ale co to jest "religia”? - pyta Charles Taylor, zarazem wyjaśniając sens i aktualność tego zagadnienia, zwracając uwagę na wielość i daleko idące zróżnicowanie zjawisk religijnych: Problemy ze zdefiniowaniem tego pojęcia [...] wynikaja przede wszystkim z tego, że zjawiska chętnie nazywane przez nas religijnymi maja ogromnie zróżnicowany charakter? Co więcej, wyznawcy danej formy wiary w nadprzyrodzoność nie zawsze zgodzą się na objęcie ich postaw i przekonań mianem „religii” („religijności”), jeśli ma być to wspólne miano także dla tych form wiary, których oni nie akceptują lub wręcz uważają za niedopuszczalne; z wnętrza swej wiary dostrzegają oni tak daleko idące różnice, które nie dopuszczają do objęcia jedną ogólną (uniwersalną, jakby zbliżającą

sprawiający wrażenie, że wszystko jest dozwolone jest swoista sygnatura naszych czasów. J. Mariański, Mtodzież między tradycją i ponowoczesnością. Wartości moralne w świadomości maturzystów, Lublin 1995, s. 31.

6 Do prób teoretycznego i empirycznego ujęcia pluralizmu można odnieść uwagę J. Mariańskiego dotyczącą - pod pewnymi względami bliskiej pluralizmowi i mającej różne oblicza - sekularyzacji: Sekularyzacja jako proces spoteczny może być opisywana na wiele sposobów i badana empirycznie na różnych ptaszczyznach. J. Mariański, Sekularyzacja - desekularyzacja - nowa duchowość, „Przegląd Religioznawczy” 2012, nr 2 (244), s. 7. Zob. K. Zielińska, Spory wokót teorii sekularyzacji, Kraków 2009; M. Hułas, Źródta sekularności. Analiza wybranych aspektów sekularyzacji, „Studia Nauk Teologicznych" 2014, Vol. 9, s. 37-53; A. Kasperek, Teoria sekularyzacji i jej wrogowie. Próba apologii niepopularnej teorii, „Prace Naukowe Akademii im. Jana Długosza w Częstochowie. Seria Pedagogika” 2009, z. 18, s. 21-34.

Ch. Taylor, Świecka epoka. Dlaczego porzucamy religię, „Dziennik” 2007, 8 XII (dodatek „Tygodnik Idei. Europa”, nr 49 (192)), s. 12. Trudności te ilustruje przykładem: Gdybyśmy mieli znaleźć punkty wspólne między życiem spoteczeństw archaicznych, w których „religia byta wszędzie”, a zespotem przekonań, praktyk $i$ instytucji podciaganych pod to pojęcie dzisiaj, to stanęlibyśmy przed trudnym, a może nawet niewykonalnym zadaniem (tamże). Problematykę zróżnicowanego zakresu znaczeń przypisywanych pojęciu „religia” rozpatruje Andrzej Bronk, Podstawy nauk o religii, Lublin 2003, Studia Religiologiczne, 4. Odnośnie do stanowiska Charlesa Taylora zob. też: D. Barnat, Świeckość jako podtoże rozumienia - zarys stanowiska Charlesa Taylora, „Diametros” 2013, nr 36, s. 1-26; M. Wojewoda, Pluralizm aksjologiczny i jego implikacje we wspótczesnej filozofii religii, Katowice 2010, Prace Naukowe Uniwersytetu Śląskiego w Katowicach, nr 2787. 
do siebie i spajającą) nazwą dalece odmiennych form wiary i kultu. To, co można próbować - z zewnątrz - opisywać jako wielość, zróżnicowanie i pluralizm świata religii, okazuje się - patrząc z wnętrza danej wiary - wprowadzaniem i narzucaniem nowych kategorii reinterpretujących tożsamość religijną, kategorii, które - unifikując i uniformizując - na jednej płaszczyźnie wielości ofert „pluralizmu religii” usiłują lokować to, co do siebie nie przystaje, i to, co się wzajemnie wyklucza. Pytania o pluralizm, zwłaszcza jako o stan zalecany, godny uczenia się, gdyż mający należycie uwzględniać walory zróżnicowania wartości w sytuacji kulturowych i światopoglądowych odmienności, stają się tym bardziej pytaniami „gorącymi” w kontekście kształtowania tożsamości religijnej.

Współczesny pluralizm - w opinii badających i konceptualizujących go socjologów - wydatnie oddziałuje na kształtowanie tożsamości religijnej i dokonuje w niej istotnych zmian. W latach 70. i 80. XX wieku wskazywano już na zachodzenie procesu pluralizacji, który modyfikująco oddziałuje na tożsamość religijną. Rozpatrując dokonujące się w społeczeństwie przemysłowym, coraz bardziej zdecydowane i zachodzące w coraz szybszym tempie, zmiany uwarunkowań działalności Kościoła jako zinstytucjonalizowanej formy wyznawania religii (przede wszystkim na przykładzie Kościoła rzymskokatolickiego), Janusz Mariański podzielał (1983) spostrzeżenie formułowane też przez innych socjologów religii, że w spoteczeństwie pluralistycznym zostaje zlikwidowana sytuacja monopolu instytucji kościelnych $w$ zakresie [...] interpretowania rzeczywistości ludzkiej w świadomości wspótczesnego cztowieka. Wartości religijne nie sa jedynymi, które nadaja sens [...] podstawowym wartościom zinstytucjonalizowanym w spoteczeństwie ${ }^{8}$. Religia przestaje więc dysponować wcześniejszymi możliwościami co najmniej potencjalnego monopolu w sferze społecznego promowania fundamentalnych wartości i formowania dominujących przekonań aksjologicznych. Pluralizm - jak sądzi Peter L. Berger, wyrażając to między innymi we wzbudzającym dyskusje akademickie i publicystyczne tekście Euroświeckosś i amerykańska religia (opublikowanym w 2005 roku) przeksztatcit religię w obu perspektywach: instytucjonalnej i indywidualnej. W wymiarze instytucjonalnym dokonało się przejście od monopolu, który sprzyja stabilizacji stanu posiadania, do co bardziej dynamicznej i budzącej niepewność konkurencji między przedkładanymi ofertami: Instytucje religijne, z których wiele przywykto do monopolu, musza sobie radzić w warunkach konkurencji. [...] wytania sie rynek religijny, $w$ ramach którego jednostki moga - wręcz musza - dokonywać wyborów. W wymiarze indywidualnym nie dziedziczy się religii, ale wybiera się ją jako jedną z możliwych opcji: $N a$ poziomie indywidualnej świadomości [...] religia nie jest już czymś przezroczystym, lecz staje się - [...] jak coraz większa część ksztattującej nas tradycji - przedmiotem namystu $i$ decyzji ${ }^{9}$. W warunkach pluralizmu te zjawiska z otaczającego człowieka świata, które

J. Mariański, Kościót w spoteczeństwie przemystowym, Warszawa 1983, s. 56.

P.L. Berger, Euroświeckość i amerykańska religia (tekst z 2005 roku), przeł. A. Bielik-Robson, [online] http://www.newsweek.pl/alternatywne-nowoczesnosci,45397,1,1.html, 2 XII 2016. Zob. A. Szahaj, Wielość, względność, obojętność? O sekularyzacji i roli religii w debacie publicznej, [w:] Nadzieje i zagrożenia sekularyzacji, red. C. Korc, R. Misiak, Szczecin 2010, s. 15-28, Studia i Rozprawy - Wydziat Teologiczny Uniwersytetu Szczecińskiego, nr 26. 
mają moc kształtowania tożsamości, nie są już tylko biernie i bezwiednie przyswajane jako forma kulturowego i religijnego przeznaczenia (przypisanego przez los, ród, etnos, wspólnotę pochodzenia, historię $)^{10}$. Treści kształtujące tożsamość są - a przynajmniej postuluje się, że powinny być - własnowolnie akceptowane jako świadomie wybrana spośród wielości innych opcja, której preferowanie wymaga, aby uczyć się jej i w ten sposób czynić ją bardziej własną niż inne opcje. Uczenie się (między innymi poznawanie i interpretowanie różnych znaczeń) utrwala dokonany wybór, mimo braku jednoznacznej i niewzruszonej oczywistości czegoś danego „z natury” („z góry”) ${ }^{11}$, czyni ten wybór w jakiejś mierze trwałym i bardziej osobistym, wpisuje go „na trwałe” w dzieje indywidualnej egzystencji.

Na dyskutowaną współcześnie i budzącą spory kwestię pluralizmu można spojrzeć w perspektywie analizy - szeroko pojmowanych - procesów i wytworów uczenia się

10 Zob. między innymi W. Świątkiewicz, Tradycja i wybór. Socjologiczne studium religijności na Górnym Ślasku, Katowice-Wrocław 1997; K. Leszczyńska, Strategie budowania wiarygodności Kościoła rzymskokatolickiego w Polsce w obliczu transformacji kulturowo-politycznej po 1989 roku, „Studia Humanistyczne AGH" 2010, Vol. 8, s. 103-115 (Religia jako niezmienna prawda jest coraz trudniejsza do uzasadnienia, zwtaszcza w sytuacji pluralizmu, który stawia koto siebie różne struktury wiarygodności, postrzegane przez jednostke jako możliwości wyboru, nie zawsze wykluczające się i skrajne aksjologicznie, tamże, s. 104); A. Różańska, Ksztattowanie się tożsamości religijnej mtodzieży w sytuacji pluralizmu kulturowego i religijnego, [w:] Socjalizacja i ksztattowanie się tożsamości - problemy i sugestie rozwiąań, red. T. Lewowicki, B. Grabowska, A. Różańska, Toruń 2008, s. 225-234; A. Pasieka, Hierarchy and Pluralism. Living Religious Difference in Catholic Poland, New York 2015; taż, How pluralism becomes hierarchical? Debating pluralism in contemporary Poland, "Sprawy Narodowościowe. Seria Nowa” 2013, nr 43, s. 53-73, [online] https://doi.org/10.11649/sn.2013.018. Agnieszka Pasieka w konkluzji stwierdza: My paper attempted to problematize the idea of pluralism by demonstrating its doubleedged character. I argued for the necessity of focusing on the contradictions and tensions that characterize pluralism and I suggested that the discussion of pluralism should be linked with the debate about multiculturalism. the two points led to the discussion of diversity and inequalities, which evinced that discrimination and hierarchy are intrinsic aspects of social relations in plural settings. I therefore suggested that the fact that the outcomes of pluralism are not only far from obvious but often contrary to what pluralism purports to achieve, should not come as surprising. What, instead, should be inquired into is the very process of the reproduction of inequalities within plural settings. that is why, the problem I aimed to address was the question of how vertical forms of differentiation are produced and made to come across as inherent, that is: how pluralism becomes hierarchical, tamże, s. 69.

11 Teza P. Bergera: Utrata religii jako czegoś absolutnie oczywistego dla świadomości jednostki oznacza, że jednostka ta jest wręcz zmuszona dokonywać wyborów, czyli korzystać ze swej „preferencji”. [...] nawet jednostka, która deklaruje przynależność do skrajnie konserwatywnej wersji tej czy innej tradycji religijnej, czyni to na zasadzie wyboru i przynajmniej podprogowo zachowuje świadomość, że istnieje możliwość odwrócenia tego wyboru w przysztości, tamże. Dokonującą się w warunkach pluralizmu relatywizację stanowisk i konieczność ich wyboru Berger mocno akcentuje: Na catym świecie ludzie mawiaja: "Jestem katolikiem, ale..." Owo „ale” oznacza pluralizacje. Spotykamy ludzi, którzy uważaja się za ortodoksów $w$ danej tradycji religijnej. Ale sposób, w jaki wyznają dane wierzenia, zmienit się. [...] wiara staje się bardziej krucha, wrażliwa. Ponieważ nie uważa się jej już za coś oczywistego, naturalnego. Jeśli coś wybieram, nie uważam tego za rzecz naturalna. Z definicji możliwość wyboru pociaga za soba możliwość rozmyślenia się. [...] religijne instytucje, w kontekśsie chrzéscijańskim, czy tego chca, czy nie, staja się dobrowolnymi stowarzyszeniami, P.L. Berger, T. Szawiel, Wojna religii z nowoczesnościa?, „Europa. Tygodnik Idei” 2007, nr 51, [online] http://wiadomosci.dziennik.pl/wydarzenia/artykuly/66327,wojna-religii-z-nowoczesnoscia.html, 2 XII 2016. 
(analizy działań edukacyjnych i autoedukacyjnych oraz ich efektów ${ }^{12}$ ). Jest to zarazem perspektywa praktyki społecznej sprzęgniętej z towarzyszącą jej refleksją. Pluralizm można postrzegać jako proces i jako wytwór wzajemnego i ustawicznego uczenia się w - mającej edukacyjny potencjał i dynamizm - relacji z osobami o mniej lub bardziej odmiennych postawach i przekonaniach ${ }^{13}$; uczenia się tych, którzy wchodząc w relacje z sobą, zachowują i zarazem kształtują swe odmienne tożsamości ${ }^{14}$. Jeśli człowiek odnajduje i wzmaga w sobie chęć ciągłego uczenia się, pomnażania poznawczo

12 Ze współczesnej debaty pedagogicznej i andragogicznej dotyczącej uczenia się zob. M. Muszyński, Edukacja i uczenie się - wokót pojęć, „Rocznik Andragogiczny” 2014, Vol. 21, s. 77-88, [online] https://doi.org/10.12775/ra.2014.004; P. Jarvis, Osobowe uczenie się w dziataniu, [w:] Kultura jako przestrzeń edukacyjna. Wspótczesne obszary uczenia się dorostych, red. W. Jakubowski, Kraków 2012, s. 9-26 (myśl Petera Jarvisa: [...] proces uczenia się lokuje się w ludzkiej biografii i spoteczno-kulturowym środowisku życia, a ich krzyżowanie się prowadzi do wytwarzania się doświadczenia, przywołuje Witold Jakubowski, Sztuka filmowa jako miejsce uczenia się, [w:] tamże, s. 112); M. Malewski, Od nauczania do uczenia się. O paradygmatycznej zmianie w andragogice, Wrocław 2010; E. Przybylska, Kultury uczenia się. Kilka refleksji w kontekście uczenia się przez cate życie, „Rocznik Andragogiczny” 2014, Vol. 21, s. 119-131, [online] https://doi.org/10.12775/ra.2014.008; J. Golonka-Legut, Uczenie sie w perspektywie biograficzności. Perspektywa andragogiczna, „Rocznik Andragogiczny” 2015, Vol. 22, s. 101-118, [online] https://doi.org/10.12775/ra.2015.005; E. Solarczyk-Ambrozik, Ksztatcenie ustawiczne w perspektywie globalnej i lokalnej. Między wymogami rynku a indywidualnymi strategiami edukacyjnymi, Poznań 2004, Psychologia i Pedagogika - Uniwersytet im. Adama Mickiewicza w Poznaniu, nr 119; E. Solarczyk-Ambrozik, Oświata dorostych w zmieniającej się rzeczywistości - między nowoczesnościa a postmodernizmem, „Chowanna” 2005, nr 2, s. 56-68.

13 Komunikowanie międzykulturowe, które jest gtównym celem edukacji, jest przekraczaniem granic wtasnej kultury, wychodzeniem na pogranicza, styki kulturowe po to, aby stawaí się bogatszym wewnętrznie, J. Nikitorowicz, Pogranicze, tożsamość, edukacja międzykulturowa, Białystok 2001, s. 8. Edukacja międzykulturowa wymaga otwartości na inne spoteczności i ich kulturę. Otwartość ta powinna [...] przejawiać się we wzajemnym oferowaniu i przyjmowaniu wartości wtaściwych różnym kulturom. [...] [To] budzi nadzieje [...] na wzajemne poznanie i wzbogacenie kultur, zblizenie ludzi, T. Lewowicki, Polityka - spoteczeństwo - edukacja. O skomplikowanych uwarunkowaniach edukacji międzykulturowej, [w:] Polityka spoteczna i oświatowa a edukacja międzykulturowa, red. T. Lewowicki, E. Ogrodzka-Mazur, CieszynWarszawa 2005, s. 19. Zob. Z. Mach, Ksztaltowanie rozumienia pluralizmu kulturowego w edukacji zjednoczonej Europy, [w:] Europa Środkowa - nowy wymiar dziedzictwa, 1991-2001, red. J. Purchla, Kraków 2002, s. 171-175; A. Sadowski, Edukacja międzykulturowa jako nabywanie kompetencji do życia w spoteczeństwie pluralistycznym, [w:] Edukacja międzykulturowa - teorie, poglady, doświadczenia spoteczne, red. T. Lewowicki, E. Ogrodzka-Mazur, Cieszyn-Warszawa-Toruń 2010, s. 101-113; E. Ogrodzka-Mazur, Edukacja międzykulturowa wobec problemów wspótczesności, „Gentes \& Nationes. Studia z Zakresu Spraw Międzynarodowych" 2012, nr 2, s. 151-163; A. Różańska, Edukacja religijna mtodzieży w warunkach pluralizmu religijnego w wybranych krajach Europy Środkowo-Wschodniej (Grupa Wyszehradzka: Polska, Czechy, Stowacja, Wegry) - studium porównawcze, Torun 2015, Edukacja Międzykulturowa.

14 Samo istnienie obok siebie osób czy grup różniacych się kulturowo nie tworzy warunków do międzykulturowości. Potrzebna jest interakcja między nimi, zwiazana z refleksyjnym podejściem do wtasnej tożsamości kulturowej, pozbawiona pokus monizmu, zawtaszczania kryterialnych symboli tożsamościowych $i$ centryzmu, M. Sobecki, Komunikacja międzykulturowa w wymiarze religijnym jako wyzwanie edukacyjne, [w:] Od wielokulturowości miejsca do międzykulturowości relacji spotecznych. Wspótczesne strategie kreowania przestrzeni życia jednostki, red. J. Nikitorowicz, J. Muszyńska, B. Boćwińska-Kiluk, Warszawa 2014, s. 112. [...] wielokulturowość to różne kultury wchodzace ze soba w wieloptaszczyznowe interakcje. Międzykulturowość to wzajemne „uczenie się kultur”, a transkulturowość to przenikanie elementów różnych kultur, czego rezultatem jest nowa jakość kulturowa, A. Śliz, M.S. Szczepański, Wielokulturowość 
wartościowej wiedzy, doskonalenia sprawności intelektualnych, to chęć ta powinna prowadzić do uznania istotnych - samoistnych i edukacyjnych - walorów odmiennych postaw i przekonań. Spotykając się z tym, co jest w jakiejś mierze inne, można się dalej uczyć oraz trafniej rozeznawać - wciąż ujawniające się - obszary własnej niewiedzy $\mathrm{i}$ ignorancji. Jest to znacząca szansa, aby lepiej poznać to, co było dotychczas obce i nieznane. A dzięki temu można przekraczać własne dotychczasowe ograniczenia.

Pluralizm byłby więc możliwy przede wszystkim jako „wzajemne uczenie się”, jednym z podstawowych warunków jego zaistnienia byłaby „wzajemna edukacja” w dość szerokim zakresie zjawisk określanych mianem „pluralizmu”. Oto uwikłane w koegzystencję jednostki i społeczności o odmiennych tożsamościach kulturowych i religijnych lub światopoglądowych chcą się od siebie uczyć, aby dzięki temu między innymi lepiej siebie rozumieć, i podejmują się takiej wzajemnej, choć niepozbawionej napięć, edukacji. Jeśli natomiast u uwikłanych w koegzystencję jednostek i społeczności zanikałaby chęć ustawicznego uczenia się pluralizmu, to tym samym zanikałby pluralizm wytwarzany, utrzymywany i wzmacniany dzięki wzajemnemu uczeniu się. Nie ma bowiem pluralizmu społecznego po prostu „danego z góry”, jako „stan natury” lub jako stan woluntarystycznie zadekretowany i zabezpieczany instytucjonalnie przez władze polityczne lub administracyjne. Wszelkiego rodzaju konstruktywistyczny technokratyzm (niezależnie od jego ideowych źródeł) nie ma mocy ustanawiania rzeczywistego pluralizmu, którego zaistnienie werbalnie proklamuje, a może narzucać wyłącznie kolejną, monolityczną formę hegemonii przypisującą sobie miano „pluralizmu”.

Uwzględniając w analizach pluralizmu wymiar „uczenia się” (edukacji), trzeba także zastanowić się, czy nie występuje w niektórych systemach (celach i treściach) nauczania osobliwy paradoks w zakresie uczenia się pluralizmu, które ma także - jak się zakłada - przezwyciężać zamkniętość przypisywaną kształtowaniu mocnej tożsamości religijnej, zwłaszcza jeśli edukacja - jak zwraca na to uwagę Peter L. Berger - pozostaje pod ścistą, scentralizowana kontrola państwową ${ }^{15}$. Czy nie dzieje się tak, że system edukacji promujący pluralizm i zarazem świeckość, traktowaną jako nadrzędna i uniwersalna wartość, w pewnym zakresie osłabia tradycyjne zróżnicowanie związane z dziedziczoną religią, a więc redukuje paletę różnorodności zjawisk kulturowych, gdyż - w imię promowania pluralizmu, silnie zespolonego ze świeckością - marginalizuje lub wręcz wyklucza religię? Europejskie scentralizowane systemy edukacyjne - stwierdza w ujęciu komparatystycznym Peter L. Berger - wydatnie przyczynity się do tego, by wykluczyć religię ze sfery publicznej, podczas gdy zdecentralizowany (a tym samym bardziej demokratyczny) system amerykański pozwolit, by uszanować wolę religijnych rodziców ${ }^{16}$. Uczenie się pluralizmu napotyka więc osobliwe paradoksy i antynomie w sferze edukacji, która

i jej socjologiczny sens. Festival Caravan czy wielokulturowe Street Party?, „Studia Socjologiczne” 2011, nr 4 (203), s. 13.

15 P.L. Berger, Euroświeckość i amerykańska religia, 2005, przel. A. Bielik-Robson, [online] http://www. newsweek.pl/alternatywne-nowoczesnosci,45397,1,1.html, 2 XII 2016.

16 Tamże. Warto tu przywołać badania Margaret Scotford Archer dotyczące różnych - scentralizowanych i zdecentralizowanych - systemów edukacji: M.S. Archer, Social Origins of Educational Systems, London 1979. O polskim kontekście deprecjonowania pluralizmu w centralizmie w systemie edukacji 
promuje określony model zespolenia pluralizmu i świeckości kosztem innych form zróżnicowania kulturowego, których występowanie - mimo ich kontrowersyjności i podnoszonych względem nich zastrzeżeń - także można uznać za manifestowanie się odmienności i pluralizmu. Przywołane dylematy edukacji uwyraźniają i konkretyzują konflikty idei i konflikty wartości, które zazwyczaj - a nawet zdaje się, że nieodłącznie - towarzyszą uczeniu się pluralizmu.

Na polskie - a także na przywoływane tu porównawczo: słowackie - doświadczenia związane ze współczesnym pluralizmem społecznym i kulturowym, a zwłaszcza z pluralizmem religijnym i światopoglądowym, z jego rozumieniem i urzeczywistnianiem można spojrzeć jako na proces indywidualnego i społecznego uczenia się pluralizmu, uczenia się stanowiącego istotny wymiar kształtowania i przemian tożsamości religijnej w kontekście kulturowych i światopoglądowych odmienności. Uczenie się pluralizmu dokonuje się w napięciu między tradycyjnym zróżnicowaniem a współczesnym pluralizmem, w próbie przechodzenia od kultywowania tradycyjnego zróżnicowania do kreowania współczesnego pluralizmu.

Wprowadzając w problematykę polskich doświadczeń i dyskusji dotyczących uczenia się pluralizmu i kształtowania tożsamości religijnej, można - na wstępie - przytoczyć charakterystyczną uwagę jednego z uczestników toczącej się debaty. Krytykując podejście polskiego katolicyzmu do pluralizmu w sferze publicznej, Jan Woleński, filozof $\mathrm{i}$ jeden z inicjatorów apelu przeciw klerykalizacji państwa, stwierdza, iż już Jan Pawet II powiedziat, że Kościót nie byt nigdy demokratyczny ani pluralistyczny. Oczywiście Kościót ma prawo do gtoszenia swoich pogladów, choć to nie jest zgodne z pluralizmem ${ }^{17}$. Słowo „pluralizm” gra w tej wypowiedzi różne role. Jeśli mimo polemiki z zasadniczymi zapatrywaniami kościelnej hierarchii wysuwa się tezę, że Kościót ma prawo do gtoszenia swoich poglądów, to czyni się tak w imię pluralizmu, a jeśli dalej dopowiada się: choć to nie jest zgodne z pluralizmem, to wskazuje na co najmniej istotną trudność w uzgadnianiu kościelnego nauczania z zasadami współczesnego pluralizmu.

Wyrażając opcję rozwijania i wzmacniania pluralizmu w życiu społecznym, Woleński zarysowuje linie rozwojowe i formułuje diagnozę: Pluralizm spoteczny w Polsce będzie się rozwijat niezależnie od Kościota. Jeśli Kościót nie stanie się pluralistyczny, to spoteczeństwo jeszcze bardziej się zsekularyzuje. $Z$ racjonalnego punktu widzenia okazuje się, $\dot{z}$ e więcej traca, broniąc monolityzmu, niż gdyby dopuścili pluralizm ${ }^{18}$. W tej wypowiedzi da się dostrzec prakseologiczne zalecenie (i pobrzmiewa w nim życzliwa sugestia), aby Kościół nie zaniedbywał uczenia się pluralizmu w procesie kształtowania tożsamości religijnej, gdyż inaczej tożsamość ta będzie ulegała osłabieniu i zanikowi. Nasuwa się przy tym pytanie, jakie dla tradycyjnie ukształtowanej tożsamości religijnej są koszta uczenia się pluralizmu. $\mathrm{Z}$ czego musi ona przede wszystkim zrezygnować i jak daleko

zob. B. Śliwerski, Diagnoza uspotecznienia publicznego szkolnictwa III RP w gorsecie centralizmu, Kraków 2013.

17 http://wyborcza.pl/1,75478,16848629,Prof_Jan_Wolenski_Kolejne_postulaty_Kosciola_psuja. html\#ixzz3HkIe7Ah6.

18 Tamże. 
mają sięgać jej przemiany, aby mogła współgrać z wymogami pluralizmu i zasługiwać na miano tożsamości pluralistycznej?

Na problemy i trudności uczenia się pluralizmu przez Kościół rzymskokatolicki w Polsce zwrócił uwagę także José Casanova w nośnej społecznie książce Public Religions in the Modern World (1994), postulującej odejście od mitycznego ujęcia powszechnego procesu sekularyzacji na rzecz badania konkretnej sytuacji ${ }^{19}$, książce po części zmieniającej sposób postrzegania społecznej roli religii. W konkluzjach analiz funkcji religii publicznej w Polsce Casanova odnosi się - w perspektywie porównawczej - do kwestii uczenia się pluralizmu: Jeśli Kościót utrzyma swoje bezkompromisowe stanowisko i będzie dążyt do narzucenia moralności katolickiej w życiu publicznym, [...] będzie niebezpieczeństwo, że instytucjonalizacja jakiejś formy polskiego narodowego katolicyzmu przeszkodzi w tworzeniu w petni otwartego i pluralistycznego polskiego spoteczeństwa obywatelskiego. Mogtaby ona także dać początek czemuś na ksztatt religijnej wojny domowej typowej dla latynoskiego modelu sekularyzacji $i^{20}$. W ocenie niektórych obserwatorów i uczestników polskiej sceny publicznej taki scenariusz w jakiejś mierze się spełnia, choć podejmując dyskusję nad taką oceną, można pytać o przyjęty model „w pełni otwartego i pluralistycznego polskiego społeczeństwa obywatelskiego" i o przyznanie pełnego prawa głosu „polskiemu narodowemu katolicyzmowi” jako jednemu z równouprawnionych podmiotów w przestrzeni publicznej pluralistycznego społeczeństwa. Czy stan „religijnej wojny domowej” jest powodowany tylko przez instytucjonalne roszczenia „narodowego katolicyzmu", który zmierza do dominacji w przestrzeni publicznej, czy być może orędownicy „w pełni otwartego i pluralistycznego polskiego społeczeństwa obywatelskiego” zbyt drastycznie ograniczają i tym samym prowokują zwolenników „narodowego katolicyzmu” do wszczynania „religijnej wojny domowej”? Jakie są zarzewia tego rodzaju „religijnej wojny domowej”? Czy uczenie się pluralizmu - a nie tylko jego nauczanie - nie jest również wymogiem wobec promotorów „w pełni otwartego i pluralistycznego polskiego społeczeństwa obywatelskiego"? Taki zestaw pytań nasuwa naszkicowana przez Casanovę jedna z wizji możliwego rozwoju sytuacji w Polsce. On sam zdaje się skłaniać do przyjęcia odmiennego, bardziej optymistycznego scenariusza, opartego o chęć uczenie się pluralizmu: Jeśli jednak gtówna teza tej książki jest stuszna, polski Kościót mógtby nauczyć się akceptować nowoczesny model sekularyzacji, a więc względnie autonomiczne różnicowanie się sfer świeckich, co wcale nie musiatoby oznaczać zgody na ostabienie lub prywatyzacje katolicyzmu w polskim spoteczeństwie obywatelskim ${ }^{21}$. Czy realizację tak zarysowanego scenariusza - bez potrzeby daleko idącego osłabienia tożsamości religijnej i jej zasadniczej prywatyzacji - zwolennicy urzeczywistniania modelu

19 Wysunął on postulat wobec socjologii religii, która - wedle jego rozeznania - powinna zastapić owo mityczne ujęcie powszechnego procesu sekularyzacji porównawczymi analizami socjologicznymi historycznych procesów sekularyzacji, odnoszącymi się do konkretnych przypadków ich występowania, J. Casanova, Religie publiczne w nowoczesnym świecie, przeł. T. Kunz, Kraków 2005, s. 42, Socjologia Religii. Tak ukierunkowane badania kształtowania się i przemian tożsamości religijnej mogą otwierać także nową przestrzeń dyskursu o roli religii w życiu publicznym.

20 Tamże, s. 194.

21 Tamże. 
otwartego i pluralistycznego społeczeństwa uznają również za spełnienie ich dążeń? W których punktach wystąpią rozbieżności stanowisk?

\title{
UCZENIE SIĘ PLURALIZMU W PERSPEKTYWIE ANALIZ METODOLOGICZNYCH I TEORII RACJONALNOŚCI
}

\begin{abstract}
Aby koncepcyjnie wzmocnić zaproponowane (i zaakcentowane w tytule) postrzeganie pluralizmu jako procesu i jako wytworu wzajemnego i ustawicznego uczenia się, warto przybliżyć analizę i idealizacyjne (modelowe) ujęcie uczenia się pluralizmu w edukacyjnej perspektywie teorii krytycznego racjonalizmu i wskazać na problemy wiążące się z uczeniem się pluralizmu. Nasuwa się też potrzeba rozpatrzenia kojarzonego z pluralizmem relatywizmu (aż po negację wartości prawdy) oraz uczenia się tolerancji dla pluralizmu interpretacji.
\end{abstract}

\section{Uczenie się pluralizmu w edukacyjnej perspektywie krytycznego racjonalizmu}

$\mathrm{Na}$ tropy edukacyjnego potencjału pluralizmu, który wymaga wzajemnego uczenia się, naprowadza Karl Raimund Popper (1902-1994)22, rozwijając koncepcję krytycznego racjonalizmu. Rozpatrując, na czym ma polegać tolerancja i intelektualna odpowiedzialność, zwraca on uwagę na możliwość i powinność wzajemnego uczenia się: $g d y$ moge uczyć się od ciebie i chcę uczyć się w interesie poszukiwania prawdy, wówczas muszę ciebie nie tylko tolerować, lecz także uznać za potencjalnie równoprawnego; potencjalna jedność i równouprawnienie wszystkich ludzi są przestanką naszej gotowości do racjonalnego dyskutowania ${ }^{23}$. Trzeba przekroczyć bariery, które sprawiają, że dane osoby lub społeczności tylko się tolerują, czyli znoszą cierpliwie uciążliwą i niepożądaną obecność. Należy się wzajemnie na siebie otworzyć, aby - mimo dzielących różnic - wejść z sobą $\mathrm{w}$ intensywniejsze relacje i prowadzić wymianę wartości.

Chęć uczenia się od innych i w ten sposób zbliżania się do lepszego poznawania prawdy zespala się z przeświadczeniem o słuszności - eksponowanej przez Poppera - zasady, iż z dyskusji możemy się wiele nauczyć; także wtedy, gdy nie prowadzi ona do zgodności. Dyskusja może nas nauczyć zrozumienia niektórych stabości naszego stanowiska. Trzeba więc być otwartym na dogłębną krytykę i samokrytykę własnego stanowiska, gdyż w większym lub mniejszym zakresie jest ono obarczone błędem, który trzeba rozpoznawać i przezwyciężać. Zachodzi ścisły związek uczenia się (poznawania)

22 Na możliwość i wręcz potrzebę uczenia się postawy intelektualnej (kształtowania moralności myślenia) w nawiązaniu do koncepcji Karla Raimunda Poppera - uwzględniając także religijny i polski kontekst - wskazuje Michał Heller w wielu swych wypowiedziach: Popperowski program krytycznego racjonalizmu pozostaje wyzwaniem, obok którego trudno przejść obojętnie. Choćby z tego względu, że idzie tu o uczciwość w myśleniu, program ten nie powinien być obcy myślicielom chrześcijanskim. Ucieczka przed uczciwościa jest po prostu grzechem, M. Heller, Chrześcijański pozytywizm, [w:] tenże, Czy fizyka jest nauka humanistyczną?, Tarnów 1998, s. 189.

23 K.R. Popper, Tolerancja i intelektualna odpowiedzialność..., s. 243. 
z otwartością na krytykę: możemy się uczyć dzięki krytyce - dzięki krytycznej dyskusji $z$ innymi i dzięki samokrytyce ${ }^{24}$. Jeśli ktoś ceni racjonalność i uważa siebie za racjonalistę, to powinien być gotowy uczyć się od innych, [...] poddaje swoje idee krytyce innych $i$ krytykuje idee innych. [...] Tylko krytyczna dyskusja może nam pomóc w postrzeganiu idei z wielu stron $i$ we wtaściwej jej ocenie ${ }^{25}$. Aby był możliwy pluralizm, niezbędne jest kształtowanie umiejętności uczestnictwa w krytycznej dyskusji, kształtowanie kultury krytycznej dyskusji. Warunkiem wzajemnego uczenia się jest respekt wobec prawdy: Możemy uczyć się od siebie wzajemnie, dopóki nie zapomnimy, że chodzi nie tylko o to, $k$ to ma rację, ile raczej o to, by zbliżyć się do obiektywnej prawdy ${ }^{26}$. Wartość prawdy zdecydowanie wysuwa się na plan pierwszy, dzięki czemu subiektywna pewność i przywiązanie do własnych preferencji stają się o wiele mniej istotne, a wręcz można i powinno się od nich odstępować w imię prawdy. Popper uważa, że szacunek dla prawdy jest istotnie jednym z najważniejszych i najcenniejszych rysów cywilizacji europejskiej i że nigdzie nie jest on zakorzeniony mocniej i gtębiej niż w nauce. Jest to bezcenny skarb, który znajdujemy w skarbnicy nauki, skarb dalece przewyższajacy, jak sądze, jej techniczna u̇̇yteczność 27 .

Wyzwaniem teoretycznym i praktycznym dla rozumienia i uczenia się pluralizmu jest relatywizm. Artykułując stanowisko właściwe - według Poppera - dla pluralizmu, wykazuje on zdecydowane różnice z relatywizmem. Przy czym zastrzega się, że stanowisko pluralizmu niemal zawsze jest mylone z relatywizmem, ale jest od niego zupetnie odmienne ${ }^{28}$. Aby uwyraźnić te odmienności, promowany pluralizm dookreśla mianem „krytycznego pluralizmu” i zwraca uwagę, że w konfrontacji relatywizmu i krytycznego pluralizmu decydujące znaczenie ma idea prawdy ${ }^{29}$. Wedle relatywizmu - tak jak prezentuje go Popper - twierdzić możemy wszystko lub prawie wszystko, a przeto nic. Wszystko jest prawdziwe lub nic. Prawda jest więc bez znaczenia ${ }^{30}$. Kwestionowanie wartości prawdy ma negatywne skutki społeczne, gdyż relatywizm, wynika[jący] zniczym nieograniczonej tolerancji, prowadzi do panowania przemocy. W przeciwieństwie do niego krytyczny pluralizm może przyczynić się do poskromienia przemocy ${ }^{31}$. Do tego wywodu można dołączyć przestrogę przed niepożądanymi skutkami relatywizmu, którą formułuje Adam Grobler: Relatywizm ma ten urok, że nikomu nie wytyka btędów, każdemu przyznaje nieomylny rozum. Niemniej kiedy wszyscy sa jednakowo kompetentni, nie ma komu rozstrzygną́ ewentualnej różnicy zdañ. A przynajmniej rozsądzić na gruncie

24 K.R. Popper, $W$ co wierzy Zachód? (skradzione od autora Społeczeństwa otwartego), [w:] tenże, $W$ poszukiwaniu lepszego świata..., s. 239.

Tamże.

Tamże, s. 240.

K.R. Popper, Epistemologia a uprzemystowienie, [w:] tenże, Mit schematu pojęciowego. Wobronie nauki i racjonalności, przeł. B. Chwedeńczuk, Warszawa 1997, s. 228.

K.R. Popper, Tolerancja i intelektualna odpowiedzialnośćc.., s. 225.

Tamże.

Tamże.

Tamże. 
rozumu. Gdy zaśargumenty nie mają swej sity, pozostaje nam jedynie sita pięśsỉi2. Relatywizm zdaje się więc uniemożliwiać uczenie się pluralizmu i tym samym niweczyć stan pluralizmu w życiu społecznym.

Krytyczny pluralizm opowiada się za praktykowaniem tolerancji i pluralizmu $\mathrm{w}$ świecie religii, akceptując wielkie uznanie dla nieskrępowanych, osobistych przekonań, [które] Oświecenie przejęto od Johna Locke’a33. Choć doświadczenie wojen religijnych i sprzeciw wobec narzucania siłą wyznawanej religii (zrozumienia, że jest rzecza beznadziejna zmuszanie terrorem do jednomyślności $w$ sferze religii) znajdują się u źródeł idei religijnej tolerancji, to nie należy tej idei postrzegać tylko jako idei negatywnej, gdyż tolerancja religijna wynika z pozytywnego przeświadczenia, że wymuszona religijna jednomyślność jest zupetnie bezwartościowa: że tylko ta wiara religijna może mieć wartość, która zostata dobrowolnie przyjęta ${ }^{34}$. Tolerancja i pluralizm zapewniają respektowanie każdej uczciwej wiary, szacunek dla jednostki i jej przekonań, uznanie godności osoby ludzkiej ${ }^{35}$. Z punktu widzenia doktrynalnych rozstrzygnięć obowiązujących wewnątrz religii (mających wykazywać prawomocność jej roszczeń) wątpliwości może budzić i budzi proponowane tu sprowadzenie aktu wyznawania wiary przede wszystkim lub wyłącznie do sfery osobistych przekonań i jednej z możliwych preferencji. Jednak zasada dobrowolności, respektująca godność osoby, staje się gwarantem wolności religijnej.

Postawa racjonalisty, który rozpoznaje ograniczenia ludzkiej kondycji epistemicznej, nie prowadzi do odrzucania wartości tradycji: Nie jesteśmy wszechwiedzący; wiemy jedynie niewiele i nie powinniśmy uważać się za wszechwiedzacych. Wtaśnie jako racjonalista wierze, że racjonalizm ma swoje granice i że bez tradycji jest niemożliwy ${ }^{36}$. Także dziedzictwo tradycji religijnej może wspierać sobą uczenie się krytycznego pluralizmu, gdyż stanowi część tradycji poszukiwań rozumu i wypracowywania argumentacji, a zwłaszcza z tej racji, iż przeciwstawia się wierze w ludzką wszechwiedzę.

$\mathrm{Ci}$, którzy żywią przekonanie o niewzruszonej i wyłącznej pewności ich stanowiska, zazwyczaj unikają otwartej dyskusji z innymi i nie chcą się uczyć od innych. Boją się, że wchodząc w otwartą dyskusję - ukierunkowaną na poznawanie prawdy - i podporządkowując się jej regułom, mogą osłabić lub stracić poczucie pewności, które dodaje im sił w ich działalności. Nie respektują oni zasad rzetelności intelektualnej, gdyż nie chodzi im o poznawanie prawdy w krytycznej dyskusji, ale o obronę i umacnianie własnych, doraźnych interesów. Do prawdy podchodzą wyłącznie instrumentalnie i za "prawdę" uważają to, co dla nich może być korzystne. $Z$ tak postępującymi osobami lub grupami trudno wchodzić w otwartą dyskusję, trudno budować pluralizm i trudno się go wzajemnie uczyć. W życiu społecznym można zaobserwować, jak osoby i grupy „dopompowujące" poczucie własnej pewności i niechcące rzetelnej dyskusji występują tak w sferze

32 A. Grobler, Cata prawda i tylko prawda, „Filozofuj” 2016, nr 3 (9), s. 9-11.

33 K.R. Popper, Tolerancja i intelektualna odpowiedzialność...

34 Tamże.

$35 \quad$ K.R. Popper, $W$ co wierzy Zachód?..., s. 242.

36 Tamże, s. 251. 
religii, jak i w sferze polityki na różnych szczeblach - od lokalnego i samorządowego po centralny i międzynarodowy. Nadzieja na rozumne opanowanie aktów przemocy ptynacych z nabożności i poczucia obowiązku okaże się ztudna, jeśli nie zrezygnujemy w sporach z postawy autorytarnej i nie będziemy gotowi uczyć się od innych ${ }^{37}$. Ponawia się tu wezwanie, aby przekształcać swą postawę, ucząc się od innych.

Aby był możliwy pluralizm - krytyczny pluralizm, a nie tylko relatywizm - niezbędna jest umiejętność wzajemnego uczenia się oraz otwarta przestrzeń krytycznej dyskusji, w której dokonuje się wymiana myśli i przyjmuje się, że warto dążyć do poznania prawdy. Jeśli niszczy się możliwość swobodnej wymiany myśli i nie respektuje się wartości prawdy, to zarazem - w zarysowanej tu perspektywie - uniemożliwia się pluralizm.

\section{Uczenie się pluralizmu w perspektywie sporu o radykalizujący się relatywizm}

Do podjęcia refleksji nad pluralizmem skłaniają też przemyślenia, które Ernest Gellner (1925-1995) poddał pod dyskusję w rozprawie Postmodernizm, rozum i religia. Rozpatruje on tam „trójdzielną sytuację”, w której wśród kształtujących intelektualne i ideowe wybory występują trzy stanowiska. Chodzi tu o fundamentalizm, deklarujący wiarę w „ostateczną prawdę”, którą ma w posiadaniu. Relatywizm negujący ideę „jedynej prawdy" i przyjmujący równoprawność odmiennych stanowisk aspirujących do wyrażania „swej prawdy”. Trzecie stanowisko to zachowanie wiary w „wyjątkowość prawdy”, przy jednoczesnym żywieniu wątpliwości, iż można ją „ostatecznie posiąśc”, a w postępowaniu praktycznym respektowanie znaczenia i roli proceduralnych rygorów, określanych przez wiarę w prawdę, natomiast powstrzymanie się od deklarowania „konkretnych przekonań" w kwestii prawdy. Fundamentaliści zastuguja na nasz szacunek, zarówno jako wspótwyznawcy tezy o unikatowości prawdy, którzy unikają tatwego oktamywania się za pomoca powszechnego relatywizmu, oraz jako nasi intelektualni przodkowie. [...] Gdyby nie powazny, by nie powiedzieć obsesyjny monoteizm i unitarianizm, racjonalny naturalizm Oświecenia równie dobrze mógt nigdy nie ujrzé́ światta dziennego. Najprawdopodobniej przywiazanie do jedynie prawdziwego Objawienia stanowito historycznie warunek wstępny pojawienia się wyjątkowej i symetrycznie dostępnej Natury ${ }^{38}$. Gellner sygnalizuje tu, iż jeśli jako racjonalista respektuje się tezę o unikatowości prawdy, to wówczas trzeba w jakiejś mierze poszerzyć horyzont racjonalności i uwzględnić także racje ludzi prezentujących mocne (fundamentalne) przeświadczenia religijne, gdyż one w pewnym zakresie mogę wspierać właściwe dla racjonalisty podejście do wyznawania wiary w prawdy.

Podobnie przed radykalizującym się relatywizmem i łączeniem go z niejako naturalnym faktem wielości i różnic przestrzega Michael Dummett: Teza o relatywności

37 K.R. Popper, Utopia a przemoc, [w:] tenże, Droga do wiedzy. Domysty i refutacje, przeł. S. Amsterdamski, Warszawa 1999, s. 592-593, Biblioteka Wspótczesnych Filozofów.

38 E. Gellner, Postmodernizm, rozum i religia, przeł. M. Kowalczuk, Warszawa 1997, s. 123, Biblioteka Myśli Wspótczesnej. Plus Minus Nieskończoność. 
prawdy jest tylko nieporozumieniem spowodowanym przez żywą świadomość różnic kulturowych $w$ różnych czasach $i$ miejscach oraz stosowanych tam i wtedy pojęć ${ }^{39}$. Wyostrzając metodologiczny krytycyzm wobec stereotypowych poglądów o relatywizmie, można unikać rozpowszechnionych nieporozumień. Choć trzeba też brać pod uwagę niełatwo poddające się całkowitemu podważeniu argumenty wysuwane na rzecz relatywizmu, czyniąc je przedmiotem analiz ${ }^{40}$.

\section{Zasada pluralizmu: uczenie się tolerancji dla pluralizmu interpretacji}

Jeśli jest się przekonanym zwolennikiem (a nawet propagatorem i wyznawcą) albo przeciwnikiem (a nawet zagorzałym przeciwnikiem) współczesnego rozumienia pluralizmu i dokonujących się zintensyfikowanych procesów pluralizacji życia społecznego, kulturowego, religijnego, a zarazem obiera się problematykę pluralizmu za przedmiot analiz mających przede wszystkim cele poznawcze, kierując się określonymi rygorami metodologii badań, to niezbędna jest wyostrzona, samokrytyczna świadomość metodologiczna. Konieczne jest wypracowanie stosownego dystansu do własnego zestawu wartości i niejawnych założeń oceniających (uprzednio przesądzających o tym, co będzie bardziej wartościowe), gdyż inaczej artykułowane przemyślenia będą się sprowadzały do głoszenia apologii (albo potępiania) pluralizmu.

Ze względów metodologicznych wymagane jest więc - na wstępie - uznanie, że z pluralizmem wiążą się różnego rodzaju teoretyczne problemy i dylematy oraz - co więcej - nie wyklucza się możliwości, że pojawiają się także praktyczne trudności i zagrożenia. Takie dość elementarne zastrzeżenia i wezwania do nieco sceptycznej powściągliwości - mimo iż zdają się oczywistością - należy przypominać, idąc między innymi za wskazaniami Marii Ossowskiej, gdy ma się do czynienia z pojęciami naznaczony$\mathrm{mi}$ (także osobistymi, egzystencjalnie doniosłymi) wartościowaniami i angażującymi emocjonalnie. Trudno wszak wymagać, aby respektowanie metodologicznych rygorów było tak dalece radykalne, że skutkowałoby przekreśleniem lub odrzuceniem własnym przekonań co do wartości pluralizmu, aby znaleźć się w całkowicie ideowo czystym, wypuryfikowanym punkcie wyjścia. Choć zawieszenie (epoché) żywionych przekonań nie jest pełne, pozostaje częściowe i warunkowe, to jednak - co ważne, zwłaszcza ze względu na analizowaną tu problematykę - pozwala na zachowanie pluralizmu, w tym przypadku jako niezbędnej dyrektywy metodologicznej w refleksji humanistycznej. Rzec można nieco paradoksalnie, że powściągliwość w wypowiadaniu się o wartości pluralizmu wymagana jest w imię respektowania pluralizmu.

Formułując przestrogę: uważajmy na tych, którzy proponują nam dyktatorskie strategie poznawcze, gdyż zazwyczaj sq sktonni do dyktatury w sensie politycznym ${ }^{41}$, Jan

39 M. Dummett, Natura i przysztość filozofii, przet. M. Iwanicki, T. Szubka, Warszawa 2010, s. 171, Klasyka Filozofii.

40 Zob. A. Chmielewski, Niewspótmierność, nieprzektadalność, konflikt. Relatywizm we wspótczesnej filozofii analitycznej, Wrocław 2014, Acta Universitatis Wratislaviensis, nr 2020.

41 J. Woleński, Racjonalizm niejedno ma imię, „Filozofuj” 2016, nr 3 (9), s. 38-39. 
Woleński rozpatruje taki sposób rozumienia racjonalności, który można uzgodnić z tolerancją dla pluralizmu interpretacji.

Poszukując w obszarze nauk humanistycznych i społecznych reguł analogicznych do teoriogrowego modelu nauk przyrodniczych (TMNP), Woleński zwraca uwagę na zasadę pluralizmu ${ }^{42}$. W TMNP nauka to Gra Badacza z Naturą. Ani Badacz, ani Natura nie dysponują strategią dyktatorską. Badacz uznaje ryzyko przegranej i wykazuje ograniczone zaufanie (aczkolwiek zaufanie) do własnych wyników; zakłada, że jego metoda może być zawodna, a uzyskane wyniki okażą się nietrwałe. Wśród cech Badacza jest krytycyzm wobec naukowych poczynań, a zarazem pewien upór w obronie wtasnego stanowiska zespolony z gotowością przyznania się do wtasnego btędu i umiejętnością uczenia się na błędach. Badacz wykazuje cechy nieobojętne etycznie, charakteryzowane w języku etyki i pozytywnie oceniane $\mathrm{z}$ moralnego punktu widzenia. Jednak TMNP nie stosuje się w pełni do nauk humanistycznych i społecznych. A te nauki wykazują dążenie do jednolitości (np. w postaci różnego typu „kamieni filozoficznych”). Aby w tych naukach unikać strategii dyktatorskiej i doktrynerstwa, potrzebna jest tolerancja dla pluralizmu interpretacji. Zasada pluralizmu pełni tu funkcję TMNP i zapewnia [...] solidne kwantum antyirracjonalizmu. Jako poszanowanie dla odmiennych perspektyw interpretacyjnych rodzi poczucie wtasnej omylności i jest przeto tama przeciwko doktrynerstwu ${ }^{43}$. TMNP i zasadę pluralizmu można zinterpretować jako wykładnię antyirracjonalizmu opartego na zasadach intersubiektywnej sprawdzalności i intersubiektywnej komunikowalności. Zasady intersubiektywności łączą się z odrzuceniem strategii dyktatorskiej i doktrynerstwa. Te zasady należy wiązać także z tezą, iż antyirracjonalista jest tylko ten, kto dopuszcza możliwość wtasnej omytki $i^{44}$. Zasada pluralizmu wpisuje się więc w określoną aksjologię badań.

\section{Argument antropologiczny za uczeniem się pluralizmu i jego respektowaniem}

Optując za zasadą pluralizmu i tolerancją dla pluralizmu interpretacji, można też przywołać antropologiczną tezę Maxa Schelera (1874-1928) z Zur Idee des Menschen (1915), wskazującą na wewnętrzne spluralizowanie człowieczeństwa: Cztowiek jest rzecza tak rozlegta, różnobarwna, różnorodna, że wszelkie definicje wypadaja zbyt kuso. Ma on zbyt wiele aspektów $w^{45}$. Rozpoznanie rzeczywistości człowieka (bumanum) w różnorodnych jej aspektach wymaga respektowania zasady pluralizmu i tolerancji dla pluralizmu interpretacji, zarazem jednak niezbędny jej sprzeciw wobec prób redukowania człowieka do jednego tylko wymiaru i podporządkowywania go tylko jednej - wykluczającej się z innymi - zasadzie. Próby definiowania człowieka tylko z punktu widzenia zradykalizowanej różnorodności i wzmożonego pluralizmu też mogą okazać się

42 Zob. J. Woleński, Aksjologia i metodologia, [w:] Etyka zawodowa ludzi nauki, red. J. Goćkowski, K. Pigoń, Wrocław-Warszawa-Kraków 1991.

Tamże, s. 78.

44 Tamże, s. 77.

45 M. Scheler, O idei cztowieka, przel. A. Węgrzecki, [w:] tenże, Pisma $z$ antropologii filozoficznej i teorii wiedzy, przeł. S. Czerniak, A. Węgrzecki, Warszawa 1987, s. 8, Biblioteka Klasyków Filozofii. 
niewystarczające, gdy pomijają ludzkie dążenia do jedności i co najmniej minimalnej jednorodności w sprawie (uzgodnienia) podstawowych wartości.

\section{UCZENIE SIE PLURALIZMU I RÓŻNE SPOSOBY JEGO ROZUMIENIA W KONTEKŚCIE KULTUROWYCH I ŚWIATOPOGLĄDOWYCH ODMIENNOŚCI}

Pluralizm we współczesnych koncepcjach i praktykach życia społecznego mieni się zgodnie ze swą etymologią - mnogością i różnorodnością znaczeń. Wielość sposobów jego rozumienia i realizowania (rzec można: „spluralizowanie i wielopostaciowość pluralizmu”) nie pozwala na wyłączne posługiwanie się tylko jedną, jakąś nadrzędną, jego formułą, która bez wątpienia odnosiłaby się do wszystkich objętych mianem pluralizmu przypadków. Choć w mocy pozostaje podstawowa intuicja doświadczania wielości i odmienności, która pozwala - dostrzegając zróżnicowanie zjawisk - mówić o pluralizmie w życiu społecznym, kulturowym i religijnym.

W kategorii pluralizmu przejawia się wielość zróżnicowanych znaczeń, gdyż z dużym natężeniem występuje ona w dyskursie potocznym, publicystycznym, ideologicznym, będąc zarazem przedmiotem analiz i istotnym elementem instrumentarium pojęciowego (ideowego, aksjologicznego) w refleksji nauk humanistycznych i społecznych oraz w dociekaniach teologicznych.

Odwołując się do kategorii pluralizmu, formułuje się (także konkurencyjne) propozycje wyjaśnienia dokonujących się obecnie przemian społecznych i cywilizacyjnych, zwłaszcza przemian w zakresie tożsamości religijnej, sytuacji wielokulturowości i kształtowania relacji międzykulturowych. Choć powinno się mieć przy tym na uwadze fakt, że sama ta kategoria używana bywa w wielu wypowiedziach w niedookreślonej postaci, nawet tylko hasłowo - jako niby samo przez się zrozumiałe hasło wywoławcze - przy założeniu, iż pożądany sens będzie uchwytny w szerszym lub węższym ideowym kontekście, do którego zawartości w danej sytuacji odwołują się użytkownicy tej kategorii. $\mathrm{Z}$ analitycznego punktu widzenia, postulującego między innymi konsekwentne respektowanie odpowiedzialności za użyte słowo, jasność i wyraźność używanych pojęć, kategoria pluralizmu wymaga więc rozjaśniającej jej sens interpretacji i uwyraźniającego jej zakres dookreślenia. Wnikając w sieć znaczeń pluralizmu, rozpoznając i systematyzując różne ich odmiany, trzeba zarazem próbować zrozumieć sytuacje i konteksty społeczne, w które kategoria pluralizmu jest uwikłana (zaangażowana).

\section{Uczenie się pluralizmu w sytuacji kontrowersji światopoglądowych}

Gdy o pluralizmie społecznym i kulturowym wypowiadają się we wspólnej debacie zwolennik sekularyzacji, który zdecydowanie optuje za laickim porządkiem życia społecznego i usytuowaniem wierzeń religijnych w sferze prywatnej, oraz ktoś z przekonaniem zaangażowany w tradycyjne (także doktrynalno-instytucjonalne) formy religii, to skonfrontowane z sobą ich opinie dotyczące pluralizmu najprawdopodobniej okażą się 
wyraźnie rozbieżne tak w warstwie opisowej (zwłaszcza w szczegółowych kwestiach), jak i - tym bardziej jeszcze - w warstwie wartościującej. Ten, kto wiąże się w swych osobistych wyborach z religią, zachowując (w dużej mierze) tradycyjną tożsamość religijną i respektując zasady obowiązujące w kościelnej postaci wyznawania wiary religijnej, ten będzie skłonny ujmować akceptowane przez siebie rozumienie pluralizmu (warunkowo akceptowane, opatrzone istotnymi zastrzeżeniami) na podobieństwo tradycyjnego zróżnicowania religijnego i światopoglądowego. Natomiast ktoś wybierający mniej lub bardziej zdecydowaną niezależność od religii - czy to będzie niezależność od tradycyjnych instytucji religijnych z zachowaniem własnej, dalece zindywidualizowanej religijności, czy też będzie to agnostycyzm lub ateizm - będzie skłaniał się do promowania i urzeczywistniania współczesnego pluralizmu związanego z osłabianiem publicznej roli religii i sekularyzacją. W takiej debacie - przeradzającej się w zasadniczy spór, w którym trzeba rozstrzygnąć: tak albo nie - trudno o wypracowanie zadowalających obie strony wspólnych uzgodnień.

Pod hasłem wartości pluralizmu zdają się skupione zasadnicze i angażujące egzystencjalnie przekonania aksjologiczne, wymagające dokonania dość radykalnych wyborów i decyzji.

\section{Uczenie się pluralizmu jako kategorii performatywnej - między zróżnicowaniem a pluralizmem}

Tradycyjnie pojmowane zróżnicowanie czy wielość były cechami zewnętrznego otoczenia, do którego - jak zalecano - trzeba z zachowaniem właściwego dystansu się ustosunkować, natomiast dzisiaj występują one jako pluralistyczne zróżnicowanie czy jako pluralistyczna wielość. Ta, zdawałoby się, redundancja, czyli zbyteczna nadmiarowość, ma swój sens. Podkreśla bowiem, iż zachodzi - w niektórych przypadkach dość radykalna transformacja tradycyjnego zróżnicowania kulturowego, zwłaszcza dotyczy to zróżnicowania religijnego. Dokonuje się przejście od form tradycyjnych do współcześnie rozumianego i praktykowanego pluralizmu, cechującego się między innymi wskazaną dwoistością (zdwojeniem). Co więcej, w ten pluralizm wpisują się dotychczasowe (dziedziczone) formy zróżnicowania, zmieniając swój charakter i funkcje, gdyż zostają one wprzęgnięte w zachodzące procesy i stają się rozsadnikami, przymnażającymi nowego pluralizmu.

Gdy wypowiada się opinię, że pluralizm stanowi jedną z cech współczesnego świata społecznego, a nasz świat - jako nasze cywilizacyjne środowisko - staje się coraz bardziej zróżnicowany kulturowo, religijnie i światopoglądowo, to pozornie wyłącznie stwierdza się stan faktyczny - takim, jaki on jest. Tego typu opinie o postępującej pluralizacji nie ograniczają się jedynie do zdania sprawy z tego, co zostało zaobserwowane. Wypowiadając te opinie - częstokroć powtarzane w niektórych środowiskach - zazwyczaj czyni się coś więcej, o wiele więcej, niż tylko przedstawia niezaangażowany, neutralny opis. Odpowiednio dobranymi (sprofilowanymi) słowami dokonuje się aktu performatywnego. Ingeruje się w rzeczywistość społeczną i działa na rzecz jej metamorfozy. Wskazując na pluralizm, jako na jedną ze swoistych cech współczesności, współtworzy się określony ideowo (silnie nasycony ideami) obraz rzeczywistości, który z pewnych (np. 
światopoglądowych) względów jest pożądanym obrazem, wzmacnia się fundujący go zespół przekonań i utrwala podstawowe schematy (stereotypy), wedle których selektywnie i wartościująco patrzy się na rzeczywistość, aby - niejako „sama z siebie” - ukazywała się ona w dużej mierze taką, jaką chce się ją postrzegać z uprzednio obranego punktu widzenia. Pluralizm bowiem to - zdaniem jego zwolenników i propagatorów - istotna wartość, którą powinno się urzeczywistniać, nawet za cenę rezygnacji z innych (tradycyjnych lub religijnych) wartości, gdyż ta właśnie wartość stanowi znaczący i niezbędny walor naszego świata, a bez niej jakość życia (tak jak się ją dziś pojmuje) uległaby osłabieniu i degradacji.

Pluralizm zaliczyć można więc do grupy kategorii performatywnych, wydatnie ukierunkowujących sposób rozumienia, postrzegania i oceniania zjawisk społecznych oraz współkształtujących przebieg tych zjawisk. $Z$ pojęciem pluralizmu ma się do czynienia tak w wymiarze teoretycznym, w badaniach i próbach koncepcyjnego opracowania przemian kulturowo-społecznych, jak też w postulowanej i urzeczywistnianej praktyce społecznej. Pluralizm nie jest więc tylko kategorią czysto teoretyczną, której stosowanie ogranicza się do wywodów i argumentacji spełniających rygory - zdystansowanej wobec dynamiki procesów społecznych - debaty akademickiej, ale stanowi też kategorię bezpośrednio zaangażowaną w działania społeczne, a jej interpretacja - również w dyskursie akademickim - bywa podporządkowana wymaganiom praxis i ewoluuje wraz z działaniami społecznymi.

Promując wartość pluralizmu, który ma wydatnie współkształtować ludzką tożsamość, wytyka się brak zrozumienia, że dialog, tolerancja, pluralizm, podmiotowość myślowa, to nie sa jedynie ogniwa mniej czy bardziej wygodnych czy godnych afirmacji rytuatów $w$ zachowaniach publicznych, ale że maja one swój gtęboki sens ontologiczny, odnoszacy się do trudnego i dla wielu nieosiagalnego (bez porzucenia starej skorupy egzystencjalnej) sposobu istnienia świata i sposobu istnienia w świecie. Ten nowy rodzaj istnienia można określić mianem istnienia pogranicznego - cztowiek pogranicza kulturowego oraz kultura pielegnująca pogranicza ludzkiego losu, to dwa aspekty równie niezbywalne i wspótkonstytuujace minimum warunków, na gruncie których pochwaty dialogu i inności oraz podmiotowości nie pachna trywialnościq $q^{46}$. Uczenie się pluralizmu - w ujęciu, które prezentuje tu Lech Witkowski - ma być kształtowaniem tożsamości człowieka pogranicza kulturowego, a taka tożsamość może być w jakiejś mierze konkurencyjna dla kształtowania tożsamości religijnej niewychodzącej (niewychylającej się) w stronę pogranicza i inności, ale trzymającej się przede wszystkim lub wyłącznie własnego doktrynalnego i obyczajowego centrum.

\section{Uczenie się jednorodności a uczenie się pluralizmu - przesłanie klasycznej edukacji humanistycznej i dylematy kształtowania tożsamości społecznej}

W klasycznie pojętej edukacji humanistycznej akcent stawiano na uczeniu się i przyswajaniu przekazu o kulturowej jednorodności. Rozpatrując rolę, którą przyznawano

46 L. Witkowski, Edukacja i humanistyka. Nowe konteksty humanistyczne dla nowoczesnych nauczycieli, Warszawa 2000, s. 162. 
poezji Homera w wychowaniu hellenistycznym, Henri Irénée Marrou (1904-1977) zwraca uwagę, że dzięki konsekwentnej edukacji humanistycznej utrzymano nietknięta ciagtość tradycji i zachowana została zasadnicza jednorodność. W wywodzie kontrastuje on to, co było udziałem edukacji starożytnych, ze współczesnym doświadczeniem zradykalizowanego zróżnicowania i pluralizmu: Podstawa [...] humanizmu jest powaga tradycji przekazywanej przez mistrzów, która się przekazuje dalej jako coś nie podlegajacego dyskusji. [...] Wielkim dobrodziejstwem jest powstajaca przez to zasadnicza jednorodność [...] wobrębie wielu pokoleń [...]. To z kolei utatwia duchowa wymiane i zespolenie. Możemy ocenić wielkość tego dobrodziejstwa, my, skazani, być zyyć wśród wspótczesnej anarchii, w której szamoce się nasza kultura ${ }^{47}$. Idealizując obraz efektów uzyskiwanych dzięki klasycznie pojętej edukacji humanistycznej, Marrou ukazuje walory ciągłości tradycji i jednorodności: Ludzie żyjący w świecie jakiejśk kultury klasycznej dziela się wszyscy wspólnym skarbem, jakim jest powszechny podziw dla tej samej rzeczy, wspólne wszystkim wzory, prawidta, a ponadto zrozumiate wszystkim przyktady, metafory, obrazy i stowa. Tak powstaje wspólny jezzyk ${ }^{48}$. I dodaje jeszcze „westchnienie”, będące dopowiedzeniem jego osobistych przekonań: Kogoż spośród ludzi wspótczesnych nie ogrania tęsknota, gdy wspomni, że taki klimat kiedyś istniat ${ }^{49}$. Nawet jeśli nie podziela się wyrażanego przez Marrou zauroczenia przekazem klasycznej edukacji humanistycznej, jeśli dostrzega się ograniczenia i braki tej edukacji, to trzeba odnotować wskazany walor ciągłości tradycji i jednorodności dla wytwarzania więzów społecznych i nabywania sprawności w komunikacji społecznej.

$\mathrm{Na}$ istotny kontrapunkt dla tego rodzaju wielości i odmienności, którą wyraża się i po części afirmuje z pomocą kategorii współczesnego pluralizmu - jako wzmożonego pluralizmu społecznego, kulturowego, religijnego - wskazuje etymologia społeczności i społeczeństwa: societas (wspólnota) i socius (towarzysz, partner, kolega), w której na plan pierwszy wysuwają się zasady służące jednoczeniu i wspólności (społem, wspólnie). Czy więc główną zasadą nadrzędną integrującą różne formy życia społecznego lub co najmniej jedną z głównych metazasad nadrzędnych - w warunkach pluralizmu ma być respektowanie zasady pluralizmu jako uprawnionego zróżnicowania wielości? Wokół trafnego rozstrzygnięcia tego pytania trwają debaty i spory, a sama zasada pluralizmu zdaje się (powinna) dopuszczać do głosu także stanowiska jej przeciwne, wyrażające troskę o jedność, gdyż stanowią one wyraz - postulowanego przez nią - zróżnicowania i odmienności.

Jeśli rozpatruje się łaciński źródłosłów pluralizmu (pluralis), to uwagę może zwracać także przejawiająca się przy próbie przekładu dwoistość znaczeń: „jeden z wielu”, jak też „należący do większej liczby”. Raz wychodzi się od faktu jednostkowości, tworzącej wielość i uwikłanej w wielość, a drugi raz - od faktu przynależności porządkującej

47 H.I. Marrou, Klasyczny humanizm, [za:] tenże, Historia wychowania w starożytności, przeł. S. Łoś, Warszawa 1969, [w:] Humanizm i edukacja humanistyczna. Wybór tekstów, red. B. Suchodolski, I. Wojnar, Warszawa 1988, s. 66.

48 Tamże.

49 Tamże. 
wielość jednostek. Ta zarysowująca się dwoistość pozwala się tak interpretować, iż $\mathrm{w}$ skrócie utrafia w istotny sens współczesnego rozumienia i praktykowania pluralizmu, który ulega co najmniej zdwojeniu. W otaczającej nas wielości i różnorodności nie tylko jest się - jako jednostka lub społeczność - czymś, co występuje jako jedno z wielu i funkcjonuje pośród mnogości innych, ale także jednostka lub społeczność nie stanowi bytu monocentrycznego i odseparowanego, lecz jednocześnie należy do większej liczby grup (kulturowych kręgów) o mniej lub bardziej odmiennych tożsamościach. A te współkonstytuujące nas różne tożsamości trzeba w zależności od sytuacji próbować z sobą uzgadniać (negocjować, dopasowywać, przeformułowywać), aby dzięki temu osłabiać i niwelować punkty zapalne i konflikty między nimi, które obecnie lokują się wewnątrz - a nie tylko na zewnętrz - tożsamości jednostki lub społeczności.

$\mathrm{Na}$ znaczenie odejścia od dawnej, właściwej tradycyjnym społecznościom, kulturowej jednorodności i jednomyślności, odejścia dokonującego się w ramach procesów pluralizacji, akcent kładzie Peter L. Berger. Za „typowo nowoczesne” zjawisko uznawano najczęściej, acz niesłusznie, świeckość, a tym fenomenem jest pluralizm. Do czasów nam współczesnych ogromna część spoteczeństw charakteryzowata się wysokim stopniem jednomyślności w podstawowych dziedzinach życia. Dziś [...] coraz silniej zaznacza się mnogość światopogladów, systemów wartości itd. Im więcej spoteczeństw przechodzi modernizacje, tym silniejszy jest pluralizm. [...] ze względu na warunki życia: urbanizacje, migracje, [...] masowa komunikacje [...] [zachodzi konieczność] dokonywania wyborów $w^{50}$. Jeśli jednak te wybory stają się głównie lub jedynie osobistymi (prywatnymi) wyborami jednostek i jeśli słabnie lub zanika stopień jednomyślności pozwalającej na organiczną integrację społeczną w oparciu o ustawiczną transmisję wspólnego dziedzictwa kulturowego (np. przekazywanego przez klasyczną edukację humanistyczną), to powstają swoiste trudności w życiu społecznym i dylematy edukacyjne. Jak bowiem w warunkach wzmożonej pluralizacji można efektywnie kształtować niezbędne minimum wspólnych przekonań, wspólnych wyobrażeń i wspólnych pojęć, niezbędne kwantum jednomyślności w kwestii podstawowych wspólnych zasad, jak wytwarzać niezbędną integrację współistniejących z sobą indywiduów?

\section{Uczenie się tego, co wspólne w modelowych ujęciach pluralizmu}

Jeśli przyjmuje się, iż zasadne i pożądane jest funkcjonowanie i rozwijanie pluralizmu, to proponując jego idealizacyjne i modelowe ujęcia, akcent kładzie się również na tym, co wspólne i co wspólnie ustalane.

W idealizacyjnym i modelowym ujęciu warunki funkcjonowania pluralizmu jako pluralistycznej wspólnoty Feliks Gross (1906-2006)51 określa następująco: Pluralizm

50 P.L. Berger, T. Szawiel, Wojna religii z nowoczesnością?, „Europa. Tygodnik Idei” 2007, nr 51, [online] http://wiadomosci.dziennik.pl/wydarzenia/artykuly/66327,wojna-religii-z-nowoczesnoscia.html, 2 XII 2016. Zob. A. Slavkovský, The holy and dirty money of faith shapes of religion in contemporary society, „Spirituality Studies” 2015, nr 1 (1), s. 113-121.

51 Zob. J. Kurczewska, Trzy role Feliksa Grossa. Zaangażowany obserwator, ideolog, uczony, [w:] F. Gross, Wartości, nauka i świadectwa epoki, Warszawa 2002, s. IX-XLII, Biblioteka Studiów Socjologicznych, 4. 
wymaga wtaściwych proporcji między odrębnościa a jednościa, między normami, które różniq, a tymi, które sq wspólne i tacza w praktyce; między grupami, których zachowanie i normy sa różne, a tymi szerszymi, wewnątrz których wszystkie grupy dziela pewne wspólne zasady i normy. Bez systemu wspólnych norm $i$ zasad proceduralnych, bez regut gry system pluralistyczny nie dziata ${ }^{52}$. Wskazuje się też, że funkcjonowanie systemu pluralistycznego między innymi wymaga: Systemu akceptowanych i podzielanych zasadniczych, wyższych norm (super-etos lub mega-etos) ${ }^{53}$. Sprawą problematyczną pozostaje zakres postulowanych proporcji i stopień akceptacji relatywizmu jako niezbędnego elementu pluralistycznego ładu. Zdaniem Grossa apriorystyczny czy absolutystyczny punkt widzenia, z wszelkimi zastrzeżeniami i względna elastycznościa, uzupetnia ów relatywistyczny $i$ uniwersalistyczny obraz ${ }^{54}$. Czyli jest tu przyjęta dopełniająca się dwoistość. Ukazuje się janusowe oblicze pluralizmu: z jednej strony relatywistyczne nastawienie, które wychodzi poza lokalności wielu absolutystycznych roszczeń w stronę uniwersalistycznego obrazu świata, z drugiej strony zarazem respektowanie elementów apriorystycznych i absolutystycznych.

\section{Iluzje i pozory uczenia się pluralizmu: „pluralizm tylko dla swoich”}

W praktyce życia społecznego bywa również tak, iż słowne deklaracje o uznawaniu i wręcz zdecydowanym promowaniu pluralizmu, jako zróżnicowania kulturowego, religijnego i światopoglądowego, nie znajdują dostatecznego pokrycia w podejmowanych działaniach. Bywa, że ci, którzy uznają pluralizm za istotną część swej tożsamości i określają samych siebie jako ideowych „zwolenników pluralizmu”, a krytykują czy wręcz napiętnują i potępiają "przeciwników pluralizmu”, w praktycznych poczynaniach (politycznych, administracyjnych, finansowych) z mniejszą lub większą determinacją marginalizują i wykluczają osoby o innych przekonaniach. A zwłaszcza ze sfery publicznej konsekwentnie eliminują tych, których ze swego subiektywnego punktu widzenia, mając na względzie jedynie osiąganie własnych korzyści, ogłaszają wrogami pluralizmu. Występuje wówczas karykaturalny „redukcjonistyczny pluralizm”, radykalnie wynaturzony „pluralizm tylko dla swoich”, bo jedynie swoich uważa się za „prawdziwych pluralistów”, którzy wyczerpują sobą całość „zróżnicowanego i wartościowego świata”, a pozostała reszta się po prostu nie liczy. Niby postulowana jest pluralistyczna różnobarwność, ale wyłącznie dla tych, którzy są w „naszych barwach” i idą pod „barwami naszego sztandaru".

Pluralizm we współczesnym świecie, który prezentuje się jako świat zróżnicowany kulturowo, religijnie i światopoglądowo, stanowi wyzwanie do pogłębionej i krytycznej refleksji. Współczesność nie jest bowiem pozbawiona niebezpieczeństwa - także podstępnego i cynicznego - wyjaławiania i ujednolicania w imię ideologicznie pojętego „pluralizmu tylko dla swoich”, który z rzeczywistą różnorodnością nie ma nic

\footnotetext{
52 F. Gross, Tolerancja i pluralizm, przeł. E. Balcerek, Warszawa 1992, s. 50.

53 Tamże, s. 51.

54 Tamże, s. 68 .
} 
wspólnego. Rzetelna promocja pluralizmu wymaga zawsze faktycznie pluralistycznej i krytycznej dyskusji przedstawicieli różnych opcji.

\section{UCZENIE SIĘ PLURALIZMU A KSZTAŁTOWANIE (KATOLICKIEJ) TOŻSAMOŚCI RELIGIJNEJ - POSZUKIWANIA I NAPIĘCIA MIĘDZY TRADYCYJNYM ZRÓŻNICOWANIEM A WSPÓŁCZESNYM PLURALIZMEM (KONTEKSTY POLSKIE I SŁOWACKIE)}

O swoistej dezorientacji w rozumieniu pluralizmu w kontekście relacji między religią i życiem społecznym, dezorientacji występującej wśród części polskich elit opiniotwórczych jeszcze pod koniec lat 80 . XX wieku zaświadcza między innymi debata „Kościół a pluralizm”, która odbyła się 9 marca 1989 roku w redakcji jezuickiego „Przeglądu Powszechnego". Temat tej debaty - jak na początku zaznacza prowadzący ją ksiądz redaktor Grzegorz Schmidt SJ: dojrzewat w naszym redakcyjnym gronie od wielu miesięcy. [...] problem obecności Kościota w pluralistycznym spoteczeństwie jest [...] zagadnieniem ważnym i interesującym ${ }^{55}$. Charakteryzując rolę Kościoła w Polsce lat 80., ks. Schmidt dzieli się swym domniemaniem, iż Kościót potrafit zachowaćswoją niezależnośćszanując spoteczne role innych instytucji, organizacji itp., dojrzewajac jak gdyby do sytuacji rodzacego się i powięszajacego pluralizmu spotecznego, gdy z jedynego reprezentanta spoteczeństwa stawat się mediatorem $[. . .]^{56}$. W tak zagajonej dyskusji wystąpił między innymi problem, co właściwie rozumieć przez „Kościól” w kontekście społecznych doświadczeń lat 80., gdyż „Kościół” był wówczas wielopostaciowy. Biskup Tadeusz Gocłowski próbował ustosunkować się do podejmowanych kwestii w języku tradycyjnej i dość apodyktycznej narracji hierarchicznej: Kościót zawsze w sposób pozytywny petnit i petni swoja funkcje w tym narodzie od tysiąca lat. Nie jest więc opozycją. A że ktoś widzi taka role Kościota jako opozycję, to już jest jego sprawa, ale Kościót w sposób pozytywny podchodzi do problemów, którymi żyje naród i chce temu narodowi stużý́ [...]. Kościót zawsze traktowat swoja obecność w narodzie w sposób stużebny ${ }^{57}$. Ksiądz Stanisław Opiela SJ odnosi się do stabszych stron Kościota w Polsce, a wśród nich do obecności Kościota w środowisku kultury i poprzez kulturę. Ksiądz Jan Sochoń (filozof) formułuje tezę: Dzisiaj, wobec pluralizmu, a więc wobec dopuszczenia różnych opinii, gtosów wewnątrz Kościota, wewnątrz wspólnoty narodowej, trzeba, żeby naród wstuchat się w nauczanie Pawta VI, a także Jana Pawta $I I^{58}$, i postuluje, aby mówiąc o pluralizmie wewnątrz Kościoła, używać określenia „pluralizm ograniczony”, mając na uwadze zbawcze posłannictwo Kościoła: „Pluralizm ograniczony" to świadomość, że Kościót daje szansę odnalezienia drogi ku zbawieniu. Dlatego niepokoją mnie gtosy niektórych uczestników naszej dyskusji, bo przecież nie jest obojętne, czy należy się do Kościota, czy nie. [...] na poziomie doktryny Kościót nie musi się

\footnotetext{
Kościót a pluralizm (debata redakcyjna), „Przegląd Powszechny” 1989, nr 7-8, s. 9.

56 Tamże.

57 Tamże, s. 12.

58 Tamże, s. 13.
} 
troszczyć o pluralizm, gdyż [...] pozostaje personalistyczny, [...] skierowany na osobę, [...] wywyższenia cztowieka w Chrystusie. [...] Dlatego pluralizm nigdy nie jest dla Kościota problemem ${ }^{59}$. W kontekście tego typu wypowiedzi strony kościelnej, formułowanych niejako w wewnętrznym języku części ludzi Kościoła, w którym „nie ma problemu pluralizmu”, wyraźnie odmiennie brzmi głos prof. Marcina Kuli, jako osoby niewierzącej, ale mającej bezpośredni kontakt z Kościołem przez swych najbliższych: Temat „Kościót a pluralizm" dotyczy mnie osobiście w sensie jak najbardziej dostownym. Podejście Kościota do pluralizmu spotecznego to m.in. podejście do niewierzacych ${ }^{60}$. I podaje przykłady takiego podejścia do osób niewierzących, których sam doświadczył i których nie może zaakceptować. Zwłaszcza chodzi o prowadzone w Kościele wychowanie religijne i katechizację, gdy nie uwzględnia się praw osób niewierzących: zgodzitem się, by moje dzieci uczestniczyty w katechizacji. Chce jednak, by moje dzieci uszanowaty, iż ktoś - poczynając od ich ojca - może nie wierzyć. Chcę, by dobieraty sobie kolegów nie wedtug kryterium wiary $[. . .]^{61}$. Te postulaty i zastrzeżenia Kula formułuje w kontekście treści podawanych jego dziecku na katechezie i zalecanych „zadań apostolskich”, z którymi był konfrontowany. Wskazane przez siebie niepożądane i sprzeczne z pluralizmem formy edukacji religijnej Kula uważa za zagrożenia [...] szczególnie istotne dla wspótpracy Kościota w niewierzacymi [...], gdy instytucje pluralizmu spotecznego stana sie faktem szerzej uznanym niz dotychczas ${ }^{62}$. Z wypowiedzi Kuli wynika ważna dla Kościoła przestroga, że jeśli zanikać będą okowy socjalistycznego państwa i coraz wyraźniejszy będzie otwarty pluralizm społeczny, to zmieni się usytuowanie Kościoła na scenie życia społecznego i dla Kościoła lepiej będzie, aby się do tego stosownie przygotował, odnajdując swe miejsce w warunkach pluralizmu. Kula zwraca też uwagę na związek Kościoła z pluralizmem, który ukształtował się w sytuacji opresji: Przez dtugi czas Kościót w Polsce reprezentowat jeden $z$ niewielu przejawów zinstytucjonalizowanego pluralizmu. Także to na co dzień mogto być watpliwym przywilejem - przynoszac ktopoty i odciagając instytucje od misji uważanej przez niq za zasadnicza. Przynosito jednocześnie pewne korzyści: przyciagato wielu do Kościota, zwiększato jego atrakcyjność, ograniczato krytycyzm wobec niego ${ }^{63}$. Czy wszakże osoby należące do Kościoła uczyły się tego pluralizmu, który Kościół niejako „z musu” reprezentował? Czy ćwiczyły i utrwalały w sobie postawy otwartości na pluralizm, które - przynajmniej z zewnątrz - uważano za szczególnie cenne?

Wypowiadając się z punktu widzenia teologii pastoralnej, badającej i wspierającej aktywność duszpasterską, ks. Adam Przybecki zwraca uwagę, że także u młodych księży po formacji seminaryjnej - dominuje zaskakujacy autokratyczny styl duszpasterzowania i catkowita nieporadność odnajdywania swego specyficznego miejsca w coraz liczniejszych ciatach kolegialnych parafii ${ }^{64}$. Negatywnie ocenia uczenie się w Kościele pluralizmu, który

\section{Tamże, s. 13-14.}

60 Tamże, s. 14.

61 Tamże, s. 15.

62 Tami̇e, s. 16.

63 Tamże.

64 Tamíe, s. 20. 
stanowi jedną z głównych cech nadchodzącej epoki: $Z$ dnia na dzień wyraźnie ksztattuje sie pluralizm spoteczno-kulturowy będacy swoista konkurencja w sferze światopogladowej. [...] do tej nowej sytuacji Kościót w Polsce nie jest jeszcze przygotowany. Eksponowanie jedynie duszpasterstwa masowego [...] oraz budowanie na [...] przeżyciowych elementach wiary jest przyktadaniem ręki do spontanicznej laicyzacji naturalnie zwiazanej z pluralizmem spoteczno-kulturowym ${ }^{65}$. Zamiast efektywnego uczenia się współczesnego pluralizmu, co jawiło się w latach 80 . XX wieku jako unikatowa szansa polskiej kultury i polskiego Kościoła katolickiego, rysuje się perspektywa wzmagającej się konfrontacji z pluralizmem, konfrontacji również zawinionej brakiem edukacji i formacji tożsamości religijnej umiejącej się odnajdywać - jeśli trzeba też polemicznie - w warunkach pluralizmu.

\section{Odkrywanie wartości tolerancji i uczenie się pluralizmu w myśli katolickiej}

Rozpatrując rozumienie wartości tolerancji i pluralizmu w myśli katolickiej, trzeba uwzględnić wyraźny dystans wobec tych kategorii, który jeszcze w połowie XX wieku cechował oficjalną doktrynę. W okresie przedsoborowym, aż do tzw. Mowy o tolerancji Piusa XII z roku 1953, Kościót katolicki odrzucat tolerancje jako zasadę życia spotecznego. Tylko szczególne powody - graves causae - ze względu na dobro wspólne mogtyby sprawić, by również btąd miat prawo do istnienia, jednak nigdy de iure, ale zawsze tylko de facto, jako konieczne pogodzenie się ze ztem, które już się stato. Przyjmując priorytet prawdy nad wolnościa, gtoszono tezę, iż prawo przystuguje wytacznie prawdzie, nigdy zaśbtędnej wie$r z e^{66}$. W imię wartości prawdy, jako wartości naczelnej także - a nawet przede wszystkim - w odniesieniu do rozumienia wiary religijnej, jako aktu wyznawania poznanej i przyjętej prawdy, negowano wolność do wyznawania błędu, do której dopuszcza się w imię wartości tolerancji i respektowania pluralizmu opinii. Wolność wiązano z prawdą i prawo do wolności miało przysługiwać tylko prawdzie, natomiast błąd miał być eliminowany, a jego upowszechnianie powstrzymywane. W ujęciu doktryny katolickiej zazwyczaj przedstawiano tezę, że jeśli wyznawanie wiary jest wyznawaniem prawdy, a prawda nie sprowadza się do wielości różnorakich opinii i opcji, to wybór prawdy, która ma moc zobowiązującą i wiąże sobą, nie może być postrzegany - również w życiu społecznym i przez władze publiczne - jako wybór spośród wielu możliwych opinii i równorzędnych opcji, które można zmieniać wedle własnych preferencji.

Analizując i uzasadniając postulat, że promowanie i respektowanie wolności religijnej - jako wolności wyznawania bądź niewyznawania danej religii - należy postrzegać również jako zadanie chrześcijan, a zwłaszcza katolików, Ernst-Wolfgang Böckenförde, profesor prawa konstytucyjnego, zwraca uwagę na doświadczenie represji skierowanych przeciw Kościołowi i napiętnowania osób wierzących w systemach totalitarnych: Kościót katolicki jest tu traktowany przez roszczacy sobie pretensje do prawdy ateizm wedle tych samych zasad, które wobec btędu i fatszu postuluje Kościót katolicki we wtasnej teorii tolerancji ${ }^{67}$.

Tamże, s. 20-21.

66 P. Mazurkiewicz, Kościót i demokracja, Warszawa 2001, s. 128-129.

67 E.-W. Böckenförde, Wolność religijna jako zadanie chrześcijan, „Znak” 1993, nr 6 (457), s. 68-78. 
Negatywne nastawienie do promowania tolerancji i pluralizmu, cechujące oficjalną doktrynę Kościoła, w zderzeniu z państwowym ateizmem okazało się zwrócone również przeciw prawom Kościoła i osób wierzących do wolności wyznania i publicznego praktykowania wiary.

\section{Współczesny pluralizm jako wyzwanie dla pasterskiego nauczania i sprawowania nauczycielskiej funkcji pasterza w religii}

Pluralizm światopoglądowy, stanowiący jedną z istotnych cech współczesnej kultury i mentalności, nabiera szczególnego znaczenia w kontekście społecznego funkcjonowania religii i zinstytucjonalizowanego wyznawania wiary religijnej, a zwłaszcza nauczycielskiej funkcji osób duchownych i ich działalności duszpasterskiej.

W socjologicznym rozpoznaniu Janusza Mariańskiego pluralizm i sekularyzacja dotykają w głównej mierze tych sfer religii, które wiążą się ze sferą aktywności duszpasterskiej: W spoteczeństwach pluralistycznych [...] dośćczęsto mówi się o kryzysie Kościota, od którego nie oczekuje się wyraźnych wskazań moralnych, lecz raczej duchowego wsparcia i pomocy. [...] kryzys Kościota dotyczy przede wszystkim instytucjonalnego postuszeństwa i jest przejawem szerszego procesu regresu zorganizowanej religii w tonie chrześcijaństwa. Sekularyzacja jako proces wyobcowania się ludzi wierzacych spod wptywów religii trwa. Kościót jest lub staje się instytucją czy wspólnotą religijna, która nie wypetnia istotnych funkcji religii, tj. nie ksztattuje życia codziennego swoich wyznawców ${ }^{68}$. Jeśli kryzys Kościota dotyczy przede wszystkim instytucjonalnego postuszensstwa $i$ jest przejawem szerszego procesu regresu zorganizowanej religii $w$ tonie chrześcijaństwa ${ }^{69}$, to kryzys ten dotyczy w dużej mierze roli duszpasterza, religijnej posługi i władzy pasterskiej, gdyż u jej podstaw zakładano określone formy instytucjonalnego - także publicznie okazywanego - posłuszeństwa wobec duszpasterza.

Współczesny pluralizm stwarza poważne wyzwania dla religii. Prezentując punkt widzenia socjologii religii, która bada i po części artykułuje (uwyraźnia) współczesne formy pluralizmu społecznego i kulturowego, Grace Davie referuje socjologiczne stanowisko, że pluralizm prowadzi do erozji struktur wiarygodności stworzonych przez

68 J. Mariański, Kościót instytucjonalny w Polsce - szanse i zagrożenia, [w:] Katolicyzm polski na przetomie wieków. Teologiczny, instytucjonalny i wspólnotowy wymiar Kościota, red. J. Baniak, Poznań 2002, s. 44, Studia i Materiaty - Uniwersytet im. Adama Mickiewicza w Poznaniu. Wydziat Teologiczny, 56. W spoteczeństwach pluralistycznych pogtębia się rozziew pomiędzy etosem spotecznym a moralnościa kościelna. Religia przesuwa się na margines życia spotecznego w zwiazku z narastajacym zjawiskiem dyferencjacji spotecznej. Staje się ona jednym z subsystemów spotecznych niemającym bezpośredniego wptywu na pozostate subsystemy spoteczne. Moralność i religia rozluźniaja swoje więzi w sferze życia zarówno prywatnego, jak i publicznego. Ewangelia proponuje swoisty maksymalizm etyczny, życie publiczne ewoluuje raczej w kierunku etycznego minimalizmu, J. Mariański, Kościót katolicki a rozwój spoteczeństwa obywatelskiego, „Rocznik Lubuski” 2003, t. 24, cz. 1, s. 126. Zob. tenże, Religia i Kościót w spoteczeństwie pluralistycznym. Polska lat dziewięćdziesiątych, Lublin 1993; tenże, Kościót katolicki w spoteczeństwie obywatelskim. Refleksje socjologiczne, Lublin 1998; tenże, Sekularyzacja i desekularyzacja w nowoczesnym świecie, Lublin 2006; W. Piwowarski, Pluralizm spoteczno-kulturowy a religia, „Roczniki Nauk Społecznych” 1980, R. 8, s. 105-123; I. Borowik, Pluralizm jako cecha przemian religijnych w kontekście transformacji w Polsce, [w:] tenże, T. Doktór, Pluralizm religijny i moralny w Polsce. Raport z badań, Kraków 2001, s. 13-46. 
monopolistyczne instytucje religijne, gdyż oferuje alternatywy dla nich. Co więcej, pluralizm stanowi nieodtaczna część modernizacji, zważywszy na coraz większa mobilność nowoczesnego świata (zarówno jeśli chodzi o ludzi, jak i idee). To wtaśnie wynikające z nowoczesności pluralistyczne tendencje okazują się niszczace dla religii ${ }^{70}$.

Użyte $\mathrm{w}$ dyskursie socjologicznym stwierdzenie, iż pluralistyczne tendencje sa niszczące dla religii, będące tu jednym z elementów koncepcji i hipotez badawczych, może zostać odczytane przez tych, dla których religia - sprawa konsekwentnego wyznawania wiary - jest bliska i ważna, jako ostrzeżenie i wezwanie do przeciwstawienia się pluralizmowi w imię obrony tradycyjnie pojętej wiary religijnej, obrony jej wizji świata i jej instytucji. Takie zaangażowane i „gorące” odczytanie skłania do formułowania radykalnej alternatywy: albo wzmagają się pluralistyczne tendencje destrukcyjne dla religii, albo religia nabiera siły, przeciwstawiając się niebezpiecznym dla niej tendencjom pluralizmu.

Socjologiczne stwierdzenie o niepożądanych dla religii skutkach pluralizmu może wszakże skłaniać osoby identyfikujące się z religią nie tylko do „larum”, ale do diagnozy i wewnętrznej krytyki religii, aby rozpoznać te jej elementy, które powodują, iż ulega ona niszczącym ją tendencjom pluralistycznym. Choć rysują się tu dwie odmienne drogi wewnętrznej diagnozy religii. Jedna fundamentalistyczna, zdecydowanego „zwarcia szeregów” i „umocnienia własnych pozycji”, gdy uzna się, że to zbyt wyeksponowane w religii elementy otwartości i dialogu osłabiają ją od wewnątrz, czyniąc ją bardziej podatną na destrukcyjne oddziaływania pluralizmu; czy wręcz że te elementy to „koń trojański” wrogiego pluralizmu, podstępnie wprowadzony do wnętrza religii. Druga droga, pogłębionego i samokrytycznego namysłu nad obecną sytuacją religii, może prowadzić do rozpoznawania wśród elementów dotychczas wpisanych w religijną tożsamość tych, które w kontekście pluralizmu są - mimo ich wielowiekowej obecności - elementami o wątpliwej wartości lub wręcz to te elementy okazują się faktycznymi - a usytuowanymi wewnątrz religii - przyczynami kryzysu osłabiającego i wyniszczającego religię. Sytuacja pluralizmu pozwala więc też oczyszczać skonfrontowaną z nią religijność, która uprzednio była zamknięta w jej jednorodnym świecie, a kryzys religii w pluralistycznym świecie może być postrzegany jako kryzys wewnętrznego dojrzewania i wzrostu.

\section{Ambiwalencja uczenia się pluralizmu i radykalizująca się krytyka pluralizmu w kościelnym nauczeniu}

Rozpatrując zasady i trudności duszpasterstwa w społeczeństwie pluralistycznym, ks. Ryszard Kamiński ${ }^{71}$, przyjmując punkt widzenia teologii pastoralnej, mającej na celu wzmacnianie efektywności działalności duszpasterskiej ${ }^{72}$, stwierdza: Spoteczeństwo pluralistyczne nie faworyzuje przekazu chrześcijańskiego, ale tworzy wtasne wartości i style życia, które sa obce albo neutralne wobec światopogladu chrześcijańskiego. W takiej sytuacji

\footnotetext{
70 G. Davie, Socjologia religii, przeł. R. Babińska, Kraków 2010, s. 88, Socjologia Religii.

71 Zob. http://www.kul.pl/ks-prof-dr-hab-ryszard-kaminski,art_10320.html.

72 O zadaniach teologii pastoralnej zob. między innymi: M. Hospodár, Pastorálna teológia, vybrané kapitoly, Prešov 2010; tenże, Pastorálna teológia. Vseobecné zásady, tajomstvo krstu, Prešov 2013.
} 
konsens dotyczacy wspólnych wartości, norm i wzorów zachowań jest niewielki, występuje bowiem wiele różnorodnych zbiorów poglądów oraz partykularnych norm i wzorów zachowań. Pluralizm zwiększa wprawdzie możliwości dokonywania osobistych wyborów, ale zarazem, sprzyja dewiacjom $i$ konfliktom ${ }^{73}$. Zasygnalizowana jest tu $-\mathrm{z}$ punktu widzenia teologii pastoralnej - ambiwalencja w ocenie społeczeństwa pluralistycznego, w którym zamierza się spełniać funkcje tradycyjnie przypisywane w religii pasterzowi (działalności duszpasterskiej).

Charakterystyczne jest negatywne waloryzowanie pluralizmu w tekście Opus Dei a wspótczesne problemy cywilizacyjne, w którym autor eksponuje dokonania Opus Dei w kontrze do słabości przypisywanych współczesności: $W$ dobie powszechnego pluralizmu i relatywizacji ethos Escrivy dąży do przezwyciężenia społecznej anomii poprzez wskazanie uniwersalnej i naczelnej wartości, jaką jest świętość. [...] Propagujac pewne wartości Opus Dei przyczynia się więc do budowania autentycznych i gtębokich relacji międzyludzkich, ale także niweluje powszechne $w$ naszej kulturze zjawisko depersonalizacji $i$ alienacji ${ }^{74}$. Podobnie negatywnie ocenił pluralizm i tolerancję częstochowski abp Wacław Depo w kazaniu wygłoszonym na Jasnej Górze, w czasie mszy świętej za Ojczyznę w 33. rocznicę stanu wojennego: Pod hastami pluralizmu poglądów, tolerancji, życia publicznego szerzy się wielka fala rugowania prawdy $i$ wartości chrześcijańskich ${ }^{75}$. Pluralizm lokuje się więc po stronie słabości i niedomagań współczesnej cywilizacji i wręcz znajduje się wśród zagrożeń występujących w aktualnej sytuacji społeczno-politycznej.

Problematyka pluralizmu występuje w wielu wiadomościach przekazywanych przez Katolicką Agencję Informacyjną i zazwyczaj bywa odpowiednio profilowana ideowo. Sprawozdanie z konferencji o stosunkach państwo-Kościół w kontekście polskiego prawa, która odbywała się na Uniwersytecie Kardynała Stefana Wyszyńskiego w Warszawie, zorganizowanej przez Wydział Prawa Kanonicznego UKSW i Stowarzyszenie Kanonistów Polskich, zatytułowano: Pluralizm światopoglądowy nie oznacza relatywizmu, a na wstępie jako tekst wytłuszczony został wybrany - wyrażający zasadniczą tezę - fragment wypowiedzi bp. Artura Mizińskiego, pełniącego funkcję sekretarza generalnego Episkopatu Polski: Pluralizm światopogladowy jest procesem nieodwracalnym, ale nie może być utożsamiany z relatywizmem lub prowadzić do uznania spoteczności państwowej jako zlaicyzowanej, czyli antyreligijnej ${ }^{76}$. W sprawozdaniu przytoczono uwagi bp. Mizińskiego o zmianach, które dokonały się w społecznej doktrynie katolickiej dzięki decyzjom

73 R. Kamiński, Duszpasterstwo w spoteczeństwie pluralistycznym, Wrocław 1997, s. 33, Teologia Praktyczna, 1; zob. też: H. Słotwińska, Pedagogika religii wobec pluralizmu religijnego, „Roczniki Teologiczne” 2014 , t. 41 , z. 11, s. 5-23.

74 J. Domaradzki, Opus Dei a wspótczesne problemy cywilizacyjne, [online] http://www.opusdei.pl/pl-pl/ article/dr-jan-domaradzki-opus-dei-a-wspoczesne-problemy-cywilizacyjne, 2 XII 2016. Zob. J. Domaradzki, Ethos pracy w doktrynie i praktyce Opus Dei, Kraków 2010.

75 http://wpolityce.pl/kosciol/225819-abp-depo-pod-haslami-pluralizmu-pogladow-tolerancji-zycia-publicznego-szerzy-sie-wielka-fala-rugowania-prawdy-i-wartosci-chrzescijanskich.

76 Pluralizm światopogladowy nie oznacza relatywizmu (lk/br, Warszawa, $20 \mathrm{~V} 2015$ ), [online] http://ekai. pl/wydarzenia/polska/x89264/pluralizm-swiatopogladowy-nie-oznacza-relatywizmu, 2 XII 2016. 
Soboru Watykańskiego II: Pluralizm światopoglądowy i religijny zastąpit wizję idealnego państwa katolickiego jako monolitu, w którym rzadzacy i rzadzeni wyznają te sama wiarę. Taki pluralizm jest procesem nieodwracalnym. [...] Konsekwencją przyjęcia faktu istnienia takiego pluralizmu w spoteczeństwie jest konieczność uznania przez Kościót świeckości państwa. Jednak zjawisko pluralizmu nie może być utożsamiane ze zjawiskiem relatywizmu prowadzacego do uznania równości różnych doktryn religijnych i wyznan wiary, ale z równościa obywateli wywodzacych się z różnych religii. Nie może też prowadzić do uznania spoteczności państwowej jako zlaicyzowanej, czyli areligijnej, antyreligijnej. W tych zastrzeżeniach wobec pluralizmu odróżnienia wymagają dwa - przenikające się tu - punkty widzenia: wewnątrzreligijny (eklezjalny) i obywatelski (publiczny). Czym innym jest uznanie w nauczaniu danej religii równości różnych doktryn religijnych i wyznań wiary, a czym innym uznanie tego rodzaju równości w przestrzeni publicznej (w sferze aktywności obywatelskiej), w której nie ma podstaw (kryteriów oceny), aby przedkładać jedne z doktryn i wyznań nad inne doktryny i wyznania.

Jeszcze mocniejsza krytyka pluralizmu występuje w tekście agencyjnym pod jednoznacznym tytułem Bp Libera: pluralizm kulturowy ponióst porażkę. Katolicka Agencja Informacyjna, przedstawiając sprawozdanie z miejskich uroczystości 950-lecia Zakroczymia, przytacza główne tezy z publicznego wystąpienia hierarchy: O tym, że w Europie nie wolno wstydzić się chrześcijaństwa i że pluralizm kulturowy ponióst porażkę, mówit bp Piotr Libera 20 września [2015] w Zakroczymiu. [...] biskupptocki przewodniczyt Eucharystii z okazji 950-lecia miasta, z udziatem parlamentarzystów i wtadz samorzadowych. Referując wywód, podkreślono: Bp Libera zaznaczat też, że „multikulti poniosto porażkę". Ci, którzy uważali inaczej, czynili to wszystko „w imię kolejnej chorej, wspótczesnej ideologii - ideologii pluralizmu", dla której wszystkie kultury, religie i wiary są dobre: „Wszystkie - z wyjątkiem jednej, wtasnej: chrześcijańskiej. Tej jednej, wtasnej się wstydza, $z$ ta jedna, wtasna, z której czerpia korzenie, walcza", komentowat hierarcha ${ }^{77}$. Pluralizm w oficjalnym kościelnym nauczaniu zostaje ukazany (napiętnowany, potępiony) jako przypadek kolejnej chorej, wspótczesnej ideologii, niszczącej dziedzictwo kultury chrześcijańskiej i zagrażającej wyznawaniu wiary.

Gdy z punktu widzenia teologii i interesów religii rozpatruje się obecność religii i trudności duszpasterstwa w społeczeństwie pluralistycznym, to częstokroć występuje retoryczna (rzec można - „kaznodziejska”) tendencja do przerysowywania niepożądanych cech pluralizmu i sekularyzacji jako zagrożeń, które swym oddziaływaniem wyraźnie osłabiają wiarę religijną w jej tradycyjnej postaci i wręcz zdają się niweczyć respektowanie „pasterskiej władzy” przez sporą liczbę wierzących, przynajmniej jeśli idzie o dotychczasowy model sprawowania władzy (posługi) religijnej. Jednak obraz pluralizmu ukazywany wyłącznie w krzywym zwierciadle religijnej krytyki wcale nie okazuje się pomocny w rzetelnym rozpoznaniu walorów i słabości współczesnej kultury.

$\mathrm{Na}$ tle przytoczonej krytyki pluralizmu odmiennie prezentują się stanowiska wyrażone przez uczestników panelu „Wspólistnienie w wielokulturowym świecie”, który

Bp Libera:pluralizm kulturowy ponióst porażkę (eg, Płock, 20 IX 2015), [online] http://ekai.pl/diecezje/plocka/x92488/bp-libera-pluralizm-kulturowy-poniosl-porazke, 2 XII 2016. 
odbył się w ramach Międzynarodowego Kongresu dla Pokoju „Ludzie i religie” 7 września 2009 roku w Krakowie. W sprawozdaniu KAI, zatytułowanym Wielokulturowość i pluralizm sq bogactwem, nie zagrożeniem, odnotowano między innymi: Arcybiskup Cotonou w Beninie - Marcel Honorat L. Agboton zwrócit uwage, że przeznaczeniem ludzi jest nie konfrontacja czy konflikt, ale dążenie do zgodnego wspótżycia w duchu wzajemnego zrozumienia $i$ tolerancji. Nasza zasada jako ludzi nie może być strach przed sasiadem, ale przeciwnie, otwarcie się na innych. Jest to zreszta nie tylko zasada, ale i koniecznościa $w$ dzisiejszym, pluralistycznym świecie ${ }^{78}$. W podobny sposób wypowiadali się inni hierarchowie uczestniczący w tym panelu i kongresie, np. kard. Lluís Maria Martínez Sistach, arcybiskup Barcelony, zwracając uwagę na duże zmiany w sktadzie wyznaniowym jego ziemi ojczystej, jak zreszta w catej Unii Europejskiej - znacznie wzróst odsetek niekatolików, gtównie prawostawnych, a także niechrześcijan, wyraził opinię: $\mathrm{Na}$ leży widzieć $w$ tym nie zagrożenie, ale [...] wyzwanie, szansę i bogactwo dla naszych Kościotó $w^{79}$. Manifestowana na kongresie - także przez cytowanych hierarchów - otwartość na wielokulturowość i pluralizm wynikała również z doboru referentów pod kątem promowanych przez kongres idei.

Do pozytywnie waloryzowanej kategorii pluralizm odwołał się brazylijski kard. Cláudio Hummes (emerytowany prefekt Kongregacji ds. Duchowieństwa), negatywnie oceniając publiczne podważanie przez czwórkę kardynałów papieskiego dokumentu Amoris laetitia: Kościót broni swojej jedności, jako jedności w wielości. [...] Jednak pluralizm zostaje zdelegitymizowany, gdy jedność jest zagrożona przez schizmę. Takie podziaty sa realnym ztem, a nie pluralizmem ${ }^{80}$. W tym ujęciu odróżnia się pożądany pluralizm, jako ,jedność w wielości”, od destrukcyjnych podziałów, zakładając przy tym określone zasady zachowania jedności i granice, w których nie tylko dopuszczalne, ale wskazane jest wyrażanie odmiennych opinii.

W toczącej się debacie występują też wypowiedzi katolickich hierarchów jakby wieszczące „koniec historii” w zakresie dotychczasowych napięć i sporów między dążeniami Kościoła katolickiego a pluralizmem zsekularyzowanego społeczeństwa. Musimy z catego serca zaakceptować kulturę, w której przyszto nam petnić nasza misję: kulture pluralistyczna, zsekularyzowane spoteczeństwo. Jestem do tego gtęboko przekonany - stwierdzał w 2016 roku prymas Belgii, obecnie kardynał, Józef de Kesel, uznając, że dzisiejsza kultura jest szansą i taska dla Kościota. Wcześniej bowiem chrześcijanie mieli oparcie w spoteczeństwie. Dziś go już nie maja, co pozwala im odkryć wolność wiary ${ }^{81}$.

78 Wielokulturowość i pluralizm sa bogactwem, nie zagrożeniem (kg/ju., Kraków, 7 IX 2009), [online] http://ekai.pl/wydarzenia/polska/x22252/wielokulturowosc-i-pluralizm-sa-bogactwem-nie-zagro zeniem, 2 XII 2016.

79 Tamże.

80 Kardynał Claudio Hummnes (fragment wywiadu dla „Religion Digital”), [online] https://dorzeczy.pl/swiat/15726/Wyrazili-watpliwosci-odnosnie-Amoris-laetitia-To-moze-doprowadzic-do-odebrania-im-kardynalatu.html, 2 XII 2016.

81 Prymas Belgii: zaakceptować zsekularyzowane spoteczeństwo (Radio Watykańskie, 13 XI 2016), [online] http://gosc.pl/doc/3550432.Prymas-Belgii-zaakceptowac-zsekularyzowane-spoleczenstwo, 2 XII 2016. 
Tego rodzaju nastawienie na gruncie polskiego katolicyzmu spotyka się wszakże ze zdecydowaną krytyką i postrzegane jest jako przejaw daleko idącej uległości wobec prądów zmierzających do sekularyzacji kultury ${ }^{82}$. Spór o wybór odpowiedniego podejścia do współczesnego radykalizującego się pluralizmu staje się więc sporem wewnątrz katolicyzmu, w którym świeccy publicyści dają zdecydowany odpór stanowisku zachodnich hierarchów reprezentujących postawę otwartą na kulturę pluralistyczną i zsekularyzowane społeczeństwo.

\section{Pasterskie nauczanie („ex katedra”) versus uczenie się pluralizmu}

Dla postrzegania w ramach kościelnego nauczania pluralizmu i sekularyzacji nie tylko jako aktualnych intelektualnych i praktycznych wyzwań, ale przede wszystkim jako bardzo poważnych i wręcz podstawowych zagrożeń, reprezentatywne wydaje się ujęcie tej kwestii, które zaprezentował bp Mariusz Leszczyński ${ }^{83}$ w referacie Akcja Katolicka świadkiem Chrystusa w epoce sekularyzacji (wygłoszonym 10 września 2011 roku podczas sympozjum z okazji 15-lecia Akcji Katolickiej diecezji bielsko-żywieckiej w Bielsku-Białej) $)^{84}$. Idąc za stanowiskiem teologii pastoralnej, któremu wyraz dał między innymi Karl-Josef Schipperges ${ }^{85}$, bp Leszczyński stwierdził: źródłem współczesnych zagrożeń dla wiary i Kościoła jest nie tylko sekularyzacja. O wiele bardziej niebezpiecznym zjawiskiem jest pluralizm polityczny i społeczny, jako jeden $z$ istotnych warunków istnienia systemu demokratycznego, a zwłaszcza pluralizm religijno-światopoglądowy, który głosi niezależność jednostki i prymat woli oraz odrzuca naturalny porządek i tradycję. Te idee powodowały w epoce nowożytnej powolną erozję religii lub jej pojawienie się w postaci zeświecczonej i wypaczonej oraz spychały ją na margines życia publicznego, doprowadzając do rozdziału religii od polityki i polityki od moralności ${ }^{86}$. Pluralizm - z punktu widzenia biskupa, który występuje tu w roli pasterza nauczającego i swym słowem umacniającego „owce” - traktuje się jako główne zagrożenie dla trwałości wiary religijnej.

W narracji bp. Leszczyńskiego, która prezentuje się jako oficjalne kościelne nauczanie o pluralizmie, rysuje się wręcz alternatywa rozłączna: albo będzie umacniał się pluralizm i tym samym będzie słabła wiara religijna (zwłaszcza będzie zanikała

82 Zob. T. Rowiński, Sekularyzacja arcybiskupstwa brukselskiego (10 XI 2015), [online] http://christianitas.org/news/sekularyzacja-arcybiskupstwa-brukselskiego, 2 XII 2016.

83 Mariusz Leszczyński, biskup pomocniczy Diecezji Zamojsko-Lubaczowskiej i Krajowy Asystent Akcji Katolickiej w Polsce (2003-2013), a obecnie także doktor habilitowany nauk teologicznych w zakresie historii Kościoła (habilitacja 2012).

84 http://akcja.diecezja.bielsko.pl/bp-mariusz-leszczynski-xv-lecie-ak.

85 Zob. K.-J. Schipperges, Religia a zeświecczone spoteczeństwo. Instrumentalizacja religii w nowożytnych systemach wtadzy politycznej, przeł. B. Floriańczyk, „Communio” 2003, nr 6, s. 65-69.

86 Bp Mariusz Leszczyński, Akcja Katolicka świadkiem Chrystusa w epoce sekularyzacji, referat wygłoszony podczas sympozjum z okazji 15-lecia Akcji Katolickiej diecezji bielsko-żywieckiej, Bielsko-Biała, 10 IX 2011, [online] http://akcja.diecezja.bielsko.pl/bp-mariusz-leszczynski-xv-lecie-ak, 2 XII 2016. 
jej publiczna manifestacja), albo wzmocni się wiara (także jej publiczna obecność), a przez jej oddziaływanie osłabną źródła, przejawy i konsekwencje pluralizmu. Dystansując się wobec bezpośredniego zaangażowania w ideową kontrowersję między pluralizmem a wiarą religijną i przyjmując w miarę neutralną pozycję, można zapytać: czy jednak kulturową koniecznością jest tak radykalny antagonizm między pluralizmem a wiarą religijną? Czy relacje między pluralizmem a wiarą religijną mogą układać się w inny, bardziej koncyliarny sposób? Jakie muszą być poczynione ustępstwa każdej ze stron i jaki będzie ich koszt dla każdej ze stron? Co powinno znaleźć się w protokole rozbieżności, gdy pozostaje poza możliwością uzgodnień i ustępstw?

Rozpatrując kwestię sekularyzacji i pluralizmu uznanych za szczególnego rodzaju niebezpieczeństwo dla zachowania i propagowania wiary religijnej, która w swej treści i formie pozostaje zgodna z nauczaniem i wymogami Kościoła, bp Leszczyński przytoczył też fragment przemówienia Benedykta XVI do biskupów Słowacji, na zakończenie wizyty ad limina Apostolorum (Watykan, 15 czerwca 2007), w którym papież zestawia z sobą tradycję i obecną sytuację religijną Słowacji i Polski: Stowacja i Polska, które we wschodniej Europie sa dwoma krajami posiadającymi najbogatsze dziedzictwo tradycji katolickiej, sq obecnie wystawione na niebezpieczeństwo, że dziedzictwo to, którego nie zdotat zniszczyć reżim komunistyczny, zostanie poważnie naruszone przez fermenty typowe dla zachodnich spoteczeństw: konsumpcjonizm, hedonizm, laicyzm, relatywizm itd. ${ }^{87}$. Dalej - zwracając uwagę na podobieństwo sytuacji religijnej Słowacji i Polski - przywołuje amerykańskiego politologa i myśliciela chrześcijańskiego, z pochodzenia Słowaka, Michaela Novaka, który w kontekście sekularyzacji Zachodu dostrzega możliwość ukształtowania się i wyartykułowania krytycznego podejścia do relatywizmu w Polsce i w Słowacji: Zachód: Francja, Niemcy, Belgia sq strasznie zsekularyzowane. Ufam, że kraje takie, jak Polska czy moja rodzinna Stowacja, moga pokazać przyktad krytycznego podejścia do relatywizmu, przyktad zaufania do chrześcijaństwa. Moga pomóc Europie odbudować jej poczucie sensu. Nie wiem, czy to się uda, ale tego wtaśnie Wam życzę. To tutaj bije serce Europy ${ }^{88}$. Wyraz przekonaniom o swoistych i częściowo wspólnych cechach słowackiej i polskiej tożsamości kulturowo-religijnej dał Michael Novak między innymi w komparatystycznym i międzykulturowym ujęciu w książce Przebudzenie etnicznej Ameryki (The Rise of the Unmeltable Ethnics, 1972) ${ }^{89}$.

87 Stowacja i Polska - najbogatsze dziedzictwo tradycji katolickiej, „Wiadomości KAI”, Biuletyn Katolickiej Agencji Informacyjnej, Warszawa, 24 VI 2007, nr 25, s. 25. Zob. R. Zenderowski, Religia a stowacka tożsamość narodowa, „Przegląd Zachodni” 2010, nr 1, s. 163-185.

${ }^{88}$ Wolność jest piękna, o ile będzie bazować na wartościach. Rozmowa z prof. M. Novakiem, amerykańskim politologiem i myślicielem chrześcijańskim, „Wiadomości KAI”, 12 VIII 2007, nr 32, s. 25. Zob. też stronę WWW http://michaelnovak.net.

89 Zob. też: R. Zenderowski, Nad Tatrami btyska się... Stowacka tożsamość narodowa w dyskursie politycznym w Republice Stowackiej (1989-2004), Warszawa 2007; tenże, Od tożsamości etnicznej ku tożsamości międzynarodowej. Stowacka tożsamość w perspektywie dyskursu politycznego (1989-2004), [w:] Państwo - spoteczeństwo - religia we wspótczesnej Europie, red. M. Mróz, T. Dębowski, Toruń 2009, s. 302-358; P. Bajda, R. Zenderowski, Polityka etniczna Stowacji, Warszawa 2016. 


\section{Nauczanie wiary i kształtowanie tożsamości religijnej a wątpliwości wobec uczenia się pluralizmu - konteksty i doświadczenia słowackie}

W środowisku słowackich teologów z Kościołów i wspólnot ewangelikalnych podjęto jako problem badawczy treści homilii w pluralistycznym świecie. Badania prowadzono w ramach grantowego projektu „Homiletická činnost cirkví v Slovenskej republike a jej dopad na kvalitu života v pluralitnej spoločnosti” (projekt VEGA 1/0070/08) ${ }^{90}$, grant ten realizowała Katedra evanjelikálnej teológie a misie Pedagogickej fakulty Univerzity Mateja Bela v Banskej Bystrici. W założeniach badań zwrócono uwagę na przyjęty sposób rozumienia i wartościowania współczesnego (zachodnioeuropejskiego) pluralizmu, który coraz wyraźniej uwidacznia się także w słowackiej przestrzeni publicznej: Pluralitná spoločnost'dnešnej Európy si zaberá čoraz väčši priestor aj v Slovenskej republike. Sformovala sa myslenim a dejinnými procesmi a vtisla podobu tvári súčasnej kultúry. Pokial'ide o krestáanskú vieru, od čias osvietenstva sa po Európe úspešne rozšírila revolta proti cirkvám, a čiastočne aj proti Bohu, ako niečomu, čo nie je prirodzené ani vedecké. Záverom toho pre určitý typ myslenia je predpoklad, že kvalita ludského života je okrem iného závislá od stupña osobného oprostenia sa od viery. Kvalitný život je v zmysle takej ideológie život v slobode, ktorú človek máspájat'ked'nie hned's ateizmom, tak aspoň sagnosticizmom a samozrejme s vedou ${ }^{11}$. Ukazuje się tu spór o sens i zakres pluralizmu, który dotyczy między innymi rozumienia ludzkiej wolności i jej granic oraz wzorców jakości życia. Wprost wyłożone jest religijne zaangażowanie w przyjętym przez autorów projektu postrzeganiu pluralizmu światopoglądowego i w krytycznej - z punktu widzenia religii - ocenie jego konsekwencji. Natomiast w opisie i ocenie współczesnego pluralizmu (wzmożonego zróżnicowania) religijnego, gdy uwzględnia się też zasadnicze cele i dążenia ekumeniczne (jedność wierzących), występuje kategoria ambiwalencji: Pluralitná spoločnost je otvorená na jednej strane pre delenie velkých celkov na malé, teda má pochopenie pre vznik nových cirkevných zoskupeni, ale súcáasne neodmieta rôzne formy konvergencie krestanských cirkvi (ekumenizmus), i ked'to nemusi nutne znamenat'volanie po organizačnej jednote všetkých cirkvi. S týmito ambivalentnými náladami musi rátat homiletická činnost cirkvi. Prajný ekumenický charakter kázania dnes viac ako v minulosti výrazne rezonuje pri percepcii a preživaní zvesti evanjelia vo vztahu ku kvalite života prijemcu. Vopačnom prípade, neekumenický, iným krestanským cirkvám a iným formám

$90 \quad$ Homiletická činnost cirkvi v Slovenskej republike a jej dopad na kvalitu života v pluralitnej spoločnosti. Monografia k výsledkom vedecko-výskumného projektu VEGA č. 1/0070/08, ed. P. Procházka, Banská Bystrica 2010. Výskumný projekt „Homiletická ćinnost cirkví v Slovenskej republike a jej dopad na kvalitu života v pluralitnej spoločnosti" sa zameral na analýzu cirkevného oblasovania evanjelia (kázania evanjelia) v bohoslužobných priestoroch (kostoloch, modlitebniach, iných) cirkvi a náboženských spoločnosti registrovaných $v$ Slovenskej republike. Pôvodným zámerom bolo skúmat' celé spektrum cirkvi registrovaných $v$ Slovenskej republike a priniest' závery všeobecne využitelné vo všetkých registrovaných cirkvách $v$ SR a poskytnút'spätnú väzbu pre výućbu teológie na vysokých školách $v S R$, avšak vzhl'adom k nedostatku finančných pro-striedkov, ktoré boli na projekt pridelené agentúrou VEGA (pridelených bolo iba 8,3\% z potrebnej sumy) musel byt' výskum obraničený čo do rozsabu a i spôsobu zberu dát, tamże, s. 13.

91 Tamże, s. 10-11; zob. też A. Mad'arová, Cirkev a pluralitná spoločnost'v SR, „Evanjelikálny teologický časopis" 2010, $\mathrm{nr} 2$, s. 56-72. 
zvestovania evanjelia neprajný charakter kázania vedie $k$ frustrácii jedných alebo $k$ posilneniu nezdravébo izolacionizmu druhých (podpora neevanjeliovej duchovnej pýchy) ${ }^{92}$. W założeniach projektu „Homiletická činnost cirkví v Slovenskej republike a jej dopad na kvalitu života v pluralitnej spoločnosti” można dostrzec - jakby samorzutnie wprowadzone - odróżnienie pluralizmu światopoglądowego, w którym mogą występować postawy areligijne i zdecydowanie antyreligijne (poddane krytycznemu osądowi), od współczesnego pluralizmu religijnego, aprobowanego jako wyraz wolności religijnej (wolności do indywidualnych decyzji w sferze wyznawania wiary religijnej), choć zarazem ambiwalentnego przez wzgląd na zobowiązującą religijną idę̨ jedności.

Zagadnienie pluralizmu uczyniono także wiodącym problemem sympozjum „Cirkev a pluralitná spoločnost"' "', które odbyło się w Żylinie 14 lutego 2009 roku, w pierwszą rocznicę utworzenia nowej rzymskokatolickiej diecezji ${ }^{94}$. To, rzec można, „znak czasu”, że kwestię pluralizmu obiera się jako wiodącą i „palącą” przy okazji świętowania kościelnych rocznic, a wymuszają ją zachodzące procesy pluralizacji i indywidualizacji w sferze religii ${ }^{95}$. Jeden z głównych referentów sympozjum „Cirkev a pluralitná spoločnost”" kard. Jozef Tomko ${ }^{96}$ rozpoczął od zarysowania tego, co najogólniej można rozumieć przez pluralizm: Pluralita znamená rôznorodost', mnohorakost', a hovorit' o mnohorakosti v spoločnosti ihned'vzbudzuje otázku, o akej pluralite chceme pojednávat ${ }^{97}$. Wskazując różne postacie i wymiary występowania pluralizmu (społecznego, etnicznego, kulturowego, religijnego), kard. Tomko proponuje spojrzenie na pluralizm przede wszystkim z punktu widzenia religii ${ }^{98}$. Wyjaśnia przy tym, dlaczego w kontekście

92 Homiletická činnost cirkví..., ed. P. Procházka, s. 12; zob. też Homiletická činnost'cirkví a kvalita súčasného života. Zborník prednášok z vedeckej teologickej konferencie, ed. A. Masarik, Banská Bystrica 2009.

Zob. http://www.tkkbs.sk/view.php?cisloclanku=20090204017.

Zob. http://zilina.sme.sk/c/4304594/dieceza-oslavi-prve-narodeniny-velkolepo.html\#ixzz3Na4P014a.

Zob. O. Štefaňak, Religia, moralność i polityka w opinii maturzystów stowackich, [w:] Narodowe czy wspólnotowe? W poszukiwaniu europejskich wartości, red. D. Gizicka, Lublin 2012, s. 85-94. Przedstawiając wnioski z badań socjologicznych, Ondrej Štefaňak stwierdza: Należy zauważý, że stosunkowo niska jest ranga przypisywana wartości „religia”. W hierarchii omawianych wartości codziennych znajduje się ona na dziewiatym z dziesięciu miejsc - wedtug najwyższej oceny („bardzo ważne”) na ósmym miejscu. Uzyskany wynik jest pewnym sygnatem dla Kościota na Stowacji, tamże, s. 86.

96 Kardynał Jozef Tomko (ur. 1924), były prefekt Kongregacji ds. Ewangelizacji Narodów (1985-2001). J. Tomko, Cirkev a pluralitná spoločnost', [w:] Cirkev a pluralitná spoločnost'. Zbornik zo sympózia pri priležitosti 1. výročia zriadenia Žilinskej diecézy, ed. Z. Pupík, Žilina 2009, s. 25.

98 Warto w tym miejscu przypomnieć analizy pluralizmu, które z punktu widzenia chrześcijańskiego humanizmu od lat 40. XX wieku prowadził słowacki filozof i teolog, w latach 1952-1965 więziony przez komunistów (skazany na 16 lat więzienia), ks. Ladislav Hanus (1907-1994), a usystematyzowane przedstawił w - napisanej w latach 1966-1967 - książce Princíp pluralizmu. Zob. L. Hanus, Princíp pluralizmu, Bratislava 1997; tam też wstęp redaktora: J. Pašteka, Hanusova výzva k pluralizmu, s. 7-23. Wydawca tak charakteryzuje treść i aktualność książki: Dielo profesora Ladislava Hanusa Princíp pluralizmu má vel'mi aktuálny obsah. Vsetci sme prešli obdobím netolerantnej totality s vel'mi obmedzenou slobodou, ktorá neumožňovala nijaký otvorený dialóg medzi občanmi a nositelmi moci. Bol to totiž „monistický" systém, kde panovala jedna trieda, jedna ideológia, jedna strana. Jeho pozitivnym náprotivkom je pluralizmus, „otvoreny” spoločenský systém. Profesor Hanus ho objasñuje filozoficky, historicky, sociologicky. Podáva kritiku liberalizmu i totalitarizmu, zabsolútnenie strany aj štátu. Upozorñuje, že pluralistická 
problemów lokalnej rzymskokatolickiej diecezji rozpatruje się kwestie globalne: Lenže dnes, $v$ dobe globalizácie a internetu, ked'celý svet je ako jedna dedina, pluralitnú spoločnost' nutne treba pozorovat' vo svetových a kontinentálnych spojoch a náväznostiach ${ }^{99}$. W rozbudowanym fragmencie wywodu, a zarazem $\mathrm{w}$ formie przestrogi dla słowackich katolików, kard. Tomko ustosunkowuje się do współczesnych form agnostycyzmu i ateizmu: agnosticizmus sa často zlieva sateizmom a stáva sa agresivnym. Má všelijaké, často hybridne formy. Popiera najmä krestanskú morálku a vyznáva akýsi humanizmus bud spochybřujúci jestvovanie Boha, alebo priam negujúci možnost' nadprirodzena. Pritom použiva zákonodarstvo alebo iné bojouné prostriedky proti viere a Cirkvi. W szczególności krytycznie odnosi się do ruchu nowego ateizmu: Príkladom tvrdého útoku proti každému náboženstvu je kniha "The God Delusion” („Sklamanie Boha” v zmysle: Boh sklamal, Boston 2006) od Američana Richarda Dawkinsa, ktorá sa vracia k starým argumentom, že viera je proti vede. Przy okazji tej polemiki Tomko wyraża tezę, że niewiara jest faktycznie „wiarą w ateizm” i staje się formą religii, gdyż wiedza nie wykazała nieistnienia Boga: Kto presvedčene neverí, robi to z určitej „viery” $v$ ateizmus, ktorý sa stáva istým druhom „náboženstva”, lebo nijaká veda nedokázala nejestvovanie Boba ${ }^{100}$. Polemizując z nowym ateizmem, kard. Tomko przypomniał doktrynalne stanowisko Kościoła katolickiego w - mającym też antropologiczny wymiar - sporze o prawdę i kwestię relatywizmu we współczesnej demokracji: Cirkev tvrdí, že rozum je o pravde a viera je tiež o pravde. Hl'adat'pravdu je najkrajšri činnost človeka. Dnes [...] uznáva sa iba „relativina”, dohodnutá, podl'a možnosti väčšinou odhlasovaná "pravda”. Toto chápanie je aj najuäčš nedostatok modernej demokracie, najmä ked' ide o základné hodnoty človeka a spoločnosti, ktoré nemožno ani zrusizt', ani volit'101. Sporą część swego wystąpienia mówca poświęcił pluralizmowi religijnemu - pojętemu przede wszystkim jako stan faktycznego zróżnicowania w zakresie koncepcji i praktyk religijnych - i toczącemu się dialogowi ekumenicznemu, sygnalizując sprawy o wymiarze globalnym (między innymi dialog międzyreligijny, w tym też dialog z islamem) ${ }^{102}$ i akcentując określony sposób

demokracia neznamená, že „v̌setko je dovolenê." Oproti tzv. negativnej slobode, ktorá vedie do destrukcie hodnôt, zdôrazñuje tzv. pozitivonu slobodu, uznávajúcu nevyhnutné viazanie na vysoké etické normy spoločenského i kultúrneho života. Tieto normy môzze zabezpečit len taký pluralisticko-demokratický štát, ktorý sa dôsledne opiera o morálne principy krestanského humanizmu (okładka, s. IV). Koncepcja pluralizmu zarysowana przez Hanusa, choć - co oczywiste - nosi piętno swego czasu, jest dziś przedmiotem teoretycznego namysłu, a także inspiruje debaty publiczne.

99 Tamże.

100 Tamże, s. 27. Kardynał przywołał też przykłady publicznych działań, które promują ateizm: Len nedávno sme boli svedkami pokusu o návrat k staropohanskému „Carpe diem!” - „Uži si dña!”, vyži sa - ked $v$ Londýne si Únia ateistov a vol'nomyšlienkárov zaplatila na verejných autobusoch plagát s nápisom: „Boh pravdepodobne nie je. Nerob si starosti a uživaj život!" Pokus zopakovali v Madride, kde však krestanskí veriaci pohotovo reagovali novým plagátom s nápisom: „Boh dozaista existuje, neváhaj žit v Kristovi!” $V$ taliánskom Janove opakovali pokus s malou obmenou, tamże.

101 Tamże, s. 28. Zob. też: P. Dancák, Filozofická teológia I. Učebný text, Prešov 2013.

102 Niekedy sa použiva pre obidva postoje jediný názov: dialóg. V tom pripade však treba rozlisiit ekumenický dialóg (medzi krestanmi) a medzináboženský dialóg (s nekrestanmi). Katolicka Cirkev nadviazala najmä po Druhom vatikánskom koncile dialóg na oboch poliach. V Rime zriadila dva príslušné úrady, dnes 
postrzegania sytuacji lokalnej: Môžeme teda povedat', že naša spoločnost'je dost' rôznorodá, pluralitná, ale s vel'kou väcšinou katolikov, s dvoma menšinovými skupinami, ktorí sa blásia k protestantskej reforme 16. storočia, s malým počtom pravoslávnych a iných krestanov - čiže existuje tu ekumenická otázka. K nej treba spomenút aj skupinku židovského náboženstva (2.310; 140 v žilinskom kraji), ktoré tvorí osobitnú otázkư ${ }^{103}$. Podsumowując dokonania i uwzględniając przeszkody dla dialogu ekumenicznego, kard. Tomko wskazał na rysującą się dwoistość: Dialóg na poli ekumenizmu vykázal v minulom roku svetlá $i$ tiene $e^{104}$. Przywołane tu krytyczne zapatrywania na współczesny pluralizm światopoglądowy i religijny, które zaprezentował między innymi kard. Tomko, można uznać za reprezentatywne dla poglądów większości oficjalnych przedstawicieli Kościoła rzymskokatolickiego, choć i w tym zakresie - co trzeba zaznaczyć, zwłaszcza mając na uwadze obecny pontyfikat Franciszka - możliwy jest pluralizm stanowisk i zmiany w sposobie ich artykułowania.

\section{Kształtowanie tożsamości współczesnego pasterza a uczenie się wyzwań pluralizmu}

Kształtowanie tożsamości współczesnego pasterza i uczenie się pluralizmu w kontekście zróżnicowania światopoglądowego i religijnego odgrywa istotną rolę w homilii abp. Cyryla Vasila SJ ${ }^{105}$, którą wygłosił 1 czerwca 2013 roku w czasie uroczystości święceń biskupich ${ }^{106}$ Milana L'acha SJ ${ }^{107}$. Wpisuje się ona w historię Kościoła greckokatolickiego w Słowacji ${ }^{108}$ i w jego homiletyczne dziedzictwo ${ }^{109}$. Ta homilia swą treścią i stylem ogniskuje

sú to: Pápežská rada pre napomáhanie jednoty krestanov a Pápežská rada pre medzináboženský dialóg. Nebudeme sa zaoberat'základnými myšlienkami a zásadami tých dvoch dialógov. Stač́ pripomenút dva najdôležitejšie koncilové dokumenty: „Unitatis redintegratio” pre ekumenizmus a „Nostra aetate” pre velké náboženstvá ako sú islam, hinduizmus, budhizmus a iné, tamże, s. 28-29.

103 Tamże, s. 29. Zob. też: F. Čitbaj, Nekatolicke cirkvi a cirkevné spoločenstvá v Slovenskej republike. Historicko-práuna reflexia, Prešov 2013.

104 Tamże.

105 Arcybiskup Cyril Vasil' SJ (ur. 1965) jest (od 2009) sekretarzem Kongregacji do spraw Kościołów Wschodnich; był (2002-2007) dziekanem Wydziału Wschodniego Prawa Kanonicznego i (2007-2009) rektorem Papieskiego Instytutu Wschodniego (Pontificio Istituto Orientale) w Rzymie. Zob. C. Vasil' SJ, Gréckokatolíci. Dejiny - osudy - osobnosti, Košice 2000; tenże, Na vlnách rádia Vatikán, Košice 2010; tenże, Krestan by mal byt' hrdinom, [w:] J. Majchrák, M. Hanus, Rozhovor s arcibiskupom Cyrilom Vasilom o rodine, utečencoch, pápežovi aj neduhoch v cirkvi, Bratilsava 2016; C. Vasil' SJ, Gréckokatolíci a jezuiti, [online] http://sk.radiovaticana.va/news/2013/06/16/vysielanie_pre_ gr\%C3\%A9ckokatol\%C3\%ADkov:_gr\%C3\%A9ckokatol\%C3\%ADci_a_jezuiti/slo-702068, 2 XII 2016.

106 O kształcie i funkcjach homilii w liturgii wschodniej zob. V. Boháč, Homiletické výzvy byzantsko-slovanskej liturgie, [w:] Kazatel'ská činnost ako integrálna súcast' novej evanjelizácie. Zbornik z medzinárodnej vedeckej konferencie, Prešov 2013, s. 90-102.

107 C. Vasil' SJ, Homilia na biskupskej vysviacke Milana L'acha (1 VI 2013, Lutina), [w:] C. Vasil', Bez súcitu vitazi nenávist.' Vybrane kázne arcibiskupa, Bratilsava 2016; zob. też: http://www.tkkbs.sk/view. php?cisloclanku=20130602006.

108 O historii i teraźniejszości Kościoła greckokatolickiego w Słowacji zob. P. Šturák, 45 rokov od obnovenia činnosti Gréckokatolíckej cirkvi v Československu, [w:] Gréckokatolícka cirkev na Slovensku vo 
w sobie główne wątki współczesnej interpretacji postawy „dobrego pasterza” w odniesieniu do duszpasterzy i hierarchów, a także stawia kwestię kształtowania tożsamości religijnej, uwzględniając przy tym przemiany i wyzwania pluralistycznego świata.

Przede wszystkim Cyryl Vasil' przypomina, czy wręcz przestrzega i napomina, że od biskupa každý očakáva v prvom rade, že bude otcom, duchovným učitelom a osobným vzorom, obrazom Krista - Dobrého pastiera ${ }^{110}$. Przez „każdy” kaznodzieja rozumie tu oczekiwania każdego, z kim spotyka się biskup, i każdego, kto spotyka się z biskupem, a nie tylko zawęża krąg „każdego” do współwyznawcy podlegającego jurysdykcji kościelnej władzy. Daleko idące zróżnicowanie ludzi zostaje w homilii zaakcentowane i zarazem skłania ono do wypracowania określonej postawy: sa budeš stretávat's rôznymi typmi ludí. Pamätaj stále, že ludia žijúci na svete, sú tu z Božej vôle a sú rozliční. Nie sú tu preto, aby bezvýhradne, automaticky a radostne plnili tvoje pokyny. Je vecou dobrých mravov, vediet použivat'slovo „Prosím” a „Ďakujem”. Słowo „proszę” ma być użyte także wówczas, gdy prawo kościelne pozwala władyce wydać polecenia: Je ale znakom skromnosti a aj istej vznešenosti duch a vediet' povedat' "prosim" aj vtedy ak máš právo dat niečo prika$z{ }^{111}$. Spotykanie się i rozmowy z ludźmi reprezentującymi zróżnicowany światopoglądowo i religijnie współczesny świat wymaga konsekwentnego - a nie tylko okazyjnego i „na pokaz” - respektowania zasad elementarnej kultury. Te zasady odzwierciedlają się także w użyciu tak prostych zwrotów, jak „proszę" i „dziękuję"112, o które wszak bywa trudno u przedstawicieli władzy (tzw. ekscelencji), przywykłych do okazywania im honorów i pierwszeństwa ${ }^{113}$.

svetle výroči III, Prešov 2013, s. 409-422; P. Šturák, Historický prierez dejinami Gréckokatolíckej cirkvi na Slovensku od počiatku ažpo súčasnost', [w:] Mariánske svätyne pol'sko-slovenského pohraničia; zborník z konferencie projektu, Prešov 2013, s. 19-38; P. Šturák, Dejiny Gréckokatolickej cirkvi v Československu v rokoch 1945-1989, Prešov 2008; P. Šturák, Prierez dejinami Gréckokatolíckej cirkvi na Slovensku, Prešov 2002.

109 Zob. L'. Petrík, Homiletická činnost v Gréckokatolíckej cirkvi na Slovensku, „Theologos: teologická revue" 2013, nr 1, s. 108-126; L'. Petrík, Viera je z počúvania a oblasovania. Homiletická interpretácia, Prešov 2013.

110 C. Vasil' SJ, Homilia na biskupskej vysviacke Milana L'acha...

111 Tamże.

112 Słowo „dziękuję” odgrywało dość ważną rolę w wypowiedzi bp. Milana Lacha SJ; którą skierował on do osób zebranych na jego święceniach; mówił między innymi do księży, ich rodzin i żon: Ďakujem vám, mili kñazi, bez vás neurobime nič, ste nám velmi potrebni. Naozaj, skláñam sa pred tým, čo robite tu na východe Slovenska, v tých podmienkach, vakých ste. Vd'aka vám za vaše svedectvo, za vaše bratstvo. D̆akujem aj vašim rodinám a manželkám, http://grkatba.sk/v-lutine-bol-vysvateny-pomocny-biskup-pre-presovsku-archieparchiu.

113 W tym kontekście warto przywołać fragment (pkt 16) z - wypracowanego przez Sobór Watykański II - Dekretu o pasterskich zadaniach biskupów w Kościele: W wykonywaniu swych zadań ojca i pasterza niech biskupi będą pośród swoich jako ci, co ustugują, niech będą dobrymi pasterzami, znającymi swe owce i przez nie znanymi, prawdziwymi ojcami, wyróżniającymi się duchem mitości i troski względem wszystkich, tak że ich wtadzy pochodzacej od Boga wszyscy sięz wdzięcznością poddają. Cata rodzinę swej trzody niech tak skupiaja i urabiają, by wszyscy, świadomi swych obowiązków, żyli i dziatali we wspólnocie mitości. By mogli to czynić skutecznie, biskupi [...] muszą tak swoje życie utożyć, by dostrajato się do wymagań czasów. 
Wykazując się poczuciem humoru i ironią, Cyryl Vasil' zwraca uwagę na dolegliwe dla otoczenia zachowania i słabości hierarchy sprawującego autorytarnie i woluntarystycznie pasterską władzę: Bolo by zlým znakom, keby si chcel mat' okolo seba len vykonávatelov Tvojej vôle, alebo takých l'udí, ktorých, ked'sa ich opýtaš kolko je hodin, tak ti povedia: „Tolko kolko poviete vy, vladyka” 114 . Przedstawiona tu w formie trafnego żartu „biskupia wyniosłość”, do której dostosować trzeba obiektywne miary upływu czasu, bywa paraliżująca dla osób i instytucji zależnych od woli i decyzji hierarchy. Kaznodzieja konfrontuje z sobą obraz „Krista - Dobrého pastiera” z obrazem „gromowładnego jedynowładcy", do którego może upodabniać się także biskup jako jedynowładca w diecezji: Obraz Jupitera, vrhajúceho z výsky Olympu hromy a blesky, či obraz jeho Veličenstva L'udovíka XIV vyhlasujúceho „Štát (resp. Cirkev) som ja!" a obklopeného len poniženými a pritakávajúcimi "poslusnými” dvoranmi a [...] poddanými, - toto nie je krestanský ideál autority vodcu ${ }^{115}$. Wymuszone posłuszeństwo jest pozorne i przejawia się tylko w zewnętrznych gestach. Kaznodzieja pod koniec homilii jeszcze raz wróci do przywar, które szczególnie grożą sprawującym władzę, i odwoła się do wspólnej ze słuchaczami kulturowej pamięci: Možno si ešte pamätáś starú pesničku českej rockovej skupiny Olympic: "Jä" opisujúcu tragikomickú figúru narcisa a egoistu ${ }^{116}$. I przytaczając między innymi ten fragment rockowego tekstu: Já, já, já, jenom já / Já, já, já, jenom já/Já stačim si sám / Já se mám, dopowiada: A rocková kapela opisuje aj koniec takéhoto smiešno-biedneho živorenia ${ }^{117}$. Ta na różne sposoby artykułowana przestroga przed egocentryczną deprawacją tych, którym powierzono władzę, powraca jak refren w treści homilii. Nie chodzi tu więc o taktyczne dostosowanie się do społecznych wymagań i „kreowanie wizerunku”, aby być postrzeganym w pożądany sposób, ale sprawa jest o wiele bardziej zasadnicza i dotyczy jakości ludzkiej egzystencji.

Uwzględniając patologie sprawowania kościelnych urzędów, abp Cyryl szczegółowo wyjaśnia sens rozbudowanej symboliki i rytuałów, które towarzyszą uroczystości święceń biskupich. Omawia omofor nakładany na biskupa unaoczniający gest niesienia na ramionach przez Chrystusa zagubionej owcy. Biskup jako dobry pasterz nie postępuje w taki sposób wobec zagubionej owcy, aby - jak ujął to Cyryl Vasil' - zahnat'ju kopancami naspät' medzi „poslušné stádo”, ale niesie ją na własnych ramionach ${ }^{118}$. Wyraziście zostaje tu zinterpretowana symbolika tej jednej owcy, o którą należy indywidualnie się zatroszczyć, a nie zahnat ju kopancami. Ci, którzy sprawują władzę nad ludźmi, także władzę duchowną, po pierwsze częstokroć przede wszystkim preferują poslušné stádo, które nie sprawia im kłopotu, i - co więcej - traktują innych ludzi, jakby mieli oni stanowić to poslušné stádo, a po drugie bliska jest im pokusa, aby indywidua odłączające się od posłusznego stada zahnat' kopancami do tego stada. Dlatego też abp Vasil' zwraca uwagę na cechy posługi pasterskiej biskupa, które są niezbędne zwłaszcza

\footnotetext{
114 C. Vasil' SJ, Homília na biskupskej vysviackej Milana Lacha...

115 Tamże.

116 Tamże.

117 Tamże.

118 Tamże.
} 
w kontekście współczesnego zróżnicowania światopoglądowego i religijnego: $W_{s z y s c y}$ wierzacy i niewierzacy, praktykujący i od Kościota formalnie oddaleni (odtaczeni), wszyscy chca widzieć w Tobie biskupa, obraz pokornego, mitujacego Chrystusa, a nie ma to być obraz finančníka, manažéra, inšpektora. Choć biskup musi umieć także zarządzać (budeš musiet' byt' tak trochu aj manažérom a inšpektorom), to jednak przede wszystkim jego tożsamość ma być ukształtowana jako tożsamość dobrego pasterza ${ }^{119}$. Obraz Jupitera i obraz Dobrego Pasterza są radykalnie przeciwstawione, jako dwie wykluczające się wizje sprawowania władzy. O ile Jupiter dąży do podporządkowania i ujednolicenia, o tyle Dobry Pasterz rozumie sytuację zróżnicowania i nie zamierza zahnat' kopancami do stada, wymuszając uległość i jedność.

Kaznodziejskie wystąpienie abp. Cyryla, które było oficjalną formą kościelnego nauczania i zostało skierowane w czasie ważnej uroczystości kościelnej do szerokiego grona bezpośrednich słuchaczy, a następnie upowszechnione na internetowych stronach Kościoła greckokatolickiego, stanowi próbę wyjścia poza utarte kościelne schematy i uwzględnienia potrzeby uczenia się pluralizmu w codziennym życiu wewnątrz i na zewnątrz Kościoła. Takie zaprezentowanie problemu kształtowania tożsamości współczesnego pasterza w kontekście wyzwań pluralizmu w dominującym kościelnym nauczaniu wydaje się jednak wyjątkiem niż regułą.

\section{Dialektyczne napięcia i zarazem dialektyczna synteza?}

W doświadczeniu uczenia się pluralizmu, z którym zmaga się współczesna myśl katolicka - tak w przypadku Polski, jak i Słowacji - dostrzec można dialektyczne napięcie i zarazem zarysowującą się dialektyczną syntezę między dążeniem do monopolu religijnego i moralnego sprawowanego przez silnie zinstytucjonalizowany i zhierarchizowany (przekonany do własnych racji) katolicyzm a pluralistycznym otwarciem właściwym dla postawy katolickości. Jeśli zaczyna dominować katolicyzm zmierzający do monopolu religijnego, moralnego i ideowego, kładący akcent na instytucjonalną i doktrynalną spójność, to wówczas aktywizują się i wzmagają siły odśrodkowe, które - wbrew monopolistycznym roszczeniom - promują katolickość jako powszechność cechującą się pluralistycznym otwarciem. Ten proces uczenia się pluralizmu jest dynamiczny i wydaje się daleki od jednoznaczności.

\section{NA ZAKOŃCZENIE: REPETITIO EST MATER STUDIORUM}

Na zakończenie - odwołując się do łacińskiej sentencji repetitio est mater studiorum warto powrócić do rozpatrzenia jednej z wypowiedzi o wartości pluralizmu i potrzebie jego uczenia się, która zawiera dość istotne przemyślenia i praktyczne wskazania, a w debacie publicznej przeszła prawie że „,bez echa” i nie wzbudziła dyskusji o tym, jak w kontekście polskich i środkowoeuropejskich doświadczeń uczyć się pluralizmu.

119 Tamże. 
W szczególnych okolicznościach historycznych, gdyż podczas gorącej drugiej tury Zjazdu „Solidarności”, występując tam 30 września 1981 roku, Józef Tischner zwrócił również uwagę zgromadzonych na kwestię pluralizmu, jego niezbędności i potrzeby uczenia się go. Jakby udzieliło się genius loci miejsca i czasu, w którym Tischner - jako myśliciel i zarazem oddziałujący formacyjnie duszpasterz - odsłaniał twórczą (osobowotwórczą, wspólnototwórczą, kulturotwórczą) moc pluralizmu: wielkością tego Zjazdu - tego oliwskiego mtyna - jest jego pluralizm. Na czym polega pluralizm? Polega nie tylko na tym, że wielu ludzi jedzie na jednym wozie i kazdy siedzi na swoim miejscu. Pluralizm to jakby wymiana spojrzeń. Idzie o to, że nikt $z$ nas nie znatby petnej prawdy o sobie, gdyby jej nie wyczytat z oczu drugiego cztowieka. Potrzebujemy nawzajem siebie, abyśmy mogli znać prawdę o sobie. Wierzacy potrzebuje oczu niewierzacego, a niewierzacy spojrzenia wierzacego. Chrześcijanin czyta prawdę o sobie nie tylko ze siebie samego i ze stów innego chrzésijanina, ale również ze spojrzenia poganina, Greka czy Żyda. Wdziedzinie prawdy obowiązuje wzajemność spojrzeń. Prawdę o polskiej kulturze czyta się nie tylko z kultury polskiej, ale również z kultury rosyjskiej, niemieckiej czy francuskiej. Nie osiagnie sięprawdy w samotności. W samotności tatwo o iluzje. Stad konieczność pluralizmu. Bez pluralizmu nie bytoby Polski, nie bytoby polskiego chrześcijaństwa, nie bytoby tego Zjazdu. To zwięźle i dobitnie wyrażone przesłanie Tischnera do uczestników Zjazdu „Solidarności” głosi, iż każdy, tak indywidualnie, jak również w wymiarze swego zaangażowania społecznego, powinien uczyć się pluralizmu, aby móc rozwijać siebie i aby mogło rozwijać się życie społeczne. Respektowanie wartości pluralizmu jest jedną z powinności tych, którzy chcą przybliżać się do poznania prawdy, bowiem $w$ dziedzinie prawdy obowiązuje wzajemność spojrzeń. Jeśli odstępuje się od respektowania pluralizmu i wzajemności spojrzeń, to nie można rzetelnie poznawać prawdy o całości złożonej rzeczywistości, ale pozostaje się tylko przy - częstokroć absolutyzowanym - wycinku, który obserwuje się z własnego punktu widzenia i w narzucającej się perspektywie własnych interesów.

Myśl Tischnera o pluralizmie - co można wyraźniej dostrzec współcześnie - trafia w zasadnicze punkty toczącej się także obecnie dyskusji o tym, czym ma być pluralizm w życiu społecznym, dyskusji o warunkach akceptacji pluralizmu i o kształtowaniu ludzkich postaw, dzięki którym pluralizm urzeczywistnia i przymnaża zróżnicowany świat wartości.

Co może zaskakiwać, ten zjazdowy, solidarnościowy manifest pluralizmu nie został podjęty w debacie publicznej przed rokiem 1989, a i po 1989 roku nie stanowił punktu odniesienia w dyskusjach i sporach na temat pluralizmu. Nie wzmacniano go argumentami przemawiającymi na jego rzecz i nie poddawano krytyce, aby wykazać słabe punkty tej linii argumentacji. Być może jednych drażniła teza, iż nikt z nas nie znatby petnejprawdy o sobie, gdyby jej nie wyczytat z oczu drugiego cztowieka, który jest inny od nas. Wierzący pewny swych racji mógł czuć się urażony sugestią, że dla poznawania prawdy o sobie potrzebuje oczu niewierzącego, i podobnie niewierzący, pewny swych racji, może nie godzić się na to, że dla poznawania prawdy o sobie potrzebuje spojrzenia wierzącego. Stawia się tu wysokie wymagania w zakresie uczenia się pluralizmu, aby wzajemność była realna, a nie tylko jawiła się jako gra pozorów ${ }^{120}$. Co więcej, Tischner

120 Zob. stanowisko, które w kwestii relacji między pluralizmem a prawdą prezentuje Andrzej Szostek; tenże, Prawda a zasada pluralizmu w dialogu spotecznym i organizacji państwa, „Ethos” 1992, Vol. 5, 
afirmuje nie tylko wartość pluralizmu, ale także wartość prawdy, a wedle niektórych stanowisk wartość pluralizmu i wartość prawdy się wykluczają: albo przyjmuje się wartość pluralizmu, albo przyjmuje się wartość prawdy. Takie skrajności nie są uznawane przez Tischnera za zasadne, tym bardziej że blisko im do fundamentalizmu niezdolnego do uczenia się pluralizmu.

Dynamika pluralizmu, postrzeganego jako wartość i zarazem warunek aktywności wartościotwórczej, stawia wyzwania, którym nie łatwo jest sprostać. Uniezależnienie pluralizmu od sfery wartości i uznanie go za stan sprzyjający zaspokajaniu indywidualnych lub grupowych potrzeb może jednakże prowadzić do tworzenia się i umacniania tożsamości zamkniętych (indywidualnych lub grupowych) monad, które w zakresie ich własnego świata mają monopol na przekonania uchodzące - wedle ich mniemania za jedynie prawdziwe ${ }^{121}$. Monady te nie potrzebują wzajemności, a pluralizm traktują przede wszystkim jako neutralną przestrzeń, w której obok siebie i całkiem niezależnie od siebie mogą funkcjonować obce sobie monady, każda w swoim świecie. Żadna z nich nie musi się uczyć pluralizmu, pozostając w swym świecie.

Jeśli jednak chce się tworzyć i rozwijać świat relacji międzyludzkich, wówczas trzeba uczyć się sztuki wzajemności i pluralizmu.

\section{BIBLIOGRAFIA}

Archer M.S., Social Origins of Educational Systems, London 1979.

Bajda P., Zenderowski R., Polityka etniczna Stowacji, Warszawa 2016.

Barnat D., Świeckość jako podtoże rozumienia - zarys stanowiska Charlesa Taylora, „Diametros” 2013, nr 36, s. 1-26.

Berger P.L., Euroświeckość i amerykańska religia (tekst z 2005 roku), przeł. A. Bielik-Robson, [online] http://www.newsweek.pl/alternatywne-nowoczesnosci,45397,1,1.html.

Berger P.L., Szawiel T., Wojna religii z nowoczesnością?, „Europa. Tygodnik Idei” 2007, nr 51, [online] http://wiadomosci.dziennik.pl/wydarzenia/artykuly/66327,wojna-religii-z-nowoczesnoscia.html.

Böckenförde E.-W., Wolność religijna jako zadanie chrześcijan, „Znak” 1993, nr 6 (457).

nr 18/19, s. 17-28; tenże, Prawda i dialog: między relatywizmem a pluralizmem, „Ethos” 1997, Vol. 10, nr 37, s. 51-63.

121 O monadycznym charakterze odizolowanych jednostek pisze też Bogumiła Truchlińska: Bachtinowskie przestanie do wspótczesności tkwi moim zdaniem w ukazaniu kulturotwórczego znaczenia różnorodności, w podkreśleniu idei polifoniczności jako podstawy dialogu. Nie muszę tu chyba podkreślać, że jest to inna wersja różnorodności niż w postmodernizmie, bo ukierunkowana na Innego czy Drugiego. Różnorodność postmodernistyczna jest ukierunkowana i jest to wielość „oboksiebna”, nie komunikująca się z sobą: wielość gtosów nie styszących się wzajemnie. Nie jest to więc pluralizm konstruktywny, kulturotwórczy. Wielość bowiem grających instrumentów nie tworzy jeszcze koncertu. Monadyczność, owa wspótczesna wersja indywidualizmu, nie może również stanowić o rozwoju kultury. O tym bowiem decyduja nie tylko poróżnienia, ale i dialog między nimi, B. Truchlińska, Dialog i poróżnienie, „Sztuka i Filozofia” 1993, nr 7, s. 300; recenzja: Przemiany wspótczesnej świadomości artystycznej: wokót postmodernizmu, red. T. Szkołut, Lublin 1992. Zob. K. Wielecki, Podmiotowość w dobie kryzysu postindustrializmu. Między indywidualizmem a kolektywizmem, Warszawa 2003. 
Boháč V., Homiletické výzvy byzantsko-slovanskej liturgie, [w:] Kazatel'ská činnost' ako integrálna súćast' novej evanjelizácie. Zbornik z medzinárodnej vedeckej konferencie, Prešov 2013.

Borowik I., Pluralizm jako cecha przemian religijnych $w$ kontekście transformacji $w$ Polsce, [w:]

I. Borowik, T. Doktór, Pluralizm religijny i moralny w Polsce. Raport z badań, Kraków 2001. Bp Libera: pluralizm kulturowy ponióst porażkę (eg, Płock, 20 IX 2015), [online] http://ekai.pl/ diecezje/plocka/x92488/bp-libera-pluralizm-kulturowy-poniosl-porazke.

Bronk A., Podstawy nauk o religii, Lublin 2003, Studia Religiologiczne, 4.

Casanova J., Religie publiczne w nowoczesnym świecie, przeł. T. Kunz, Kraków 2005, Socjologia Religii.

Chmielewski A., Niewspótmierność, nieprzektadalność, konflikt. Relatywizm we wspótczesnej filozofii analitycznej, Wrocław 2014, Acta Universitatis Wratislaviensis, nr 2020.

Čitbaj F., Nekatolicke cirkvi a cirkevné spoločenstvá v Slovenskej republike. Historicko-právna reflexia, Prešov 2013.

Dancák P., Filozofická teológia I. Učebný text, Prešov 2013.

Davie G., Socjologia religii, przeł. R. Babińska, Kraków 2010, Socjologia Religii.

Domaradzki J., Ethos pracy w doktrynie i praktyce Opus Dei, Kraków 2010.

Domaradzki J., Opus Dei a wspótczesne problemy cywilizacyjne, [online] http://www.opusdei.pl/ $\mathrm{pl-pl/article/dr-jan-domaradzki-opus-dei-a-wspoczesne-problemy-cywilizacyjne.}$

Dummett M., Natura i przysztość filozofii, przeł. M. Iwanicki, T. Szubka, Warszawa 2010, Klasyka Filozofii.

Gellner E., Postmodernizm, rozum i religia, przeł. M. Kowalczuk, Warszawa 1997, Biblioteka Myśli Wspótczesnej. Plus Minus Nieskończoność.

Golonka-Legut J., Uczenie się w perspektywie biograficzności. Perspektywa andragogiczna, „Rocznik Andragogiczny” 2015, Vol. 22, [online] https://doi.org/10.12775/ra.2015.005.

Grobler A., Cata prawda i tylko prawda, „Filozofuj” 2016, nr 3 (9).

Gross F., Tolerancja i pluralizm, przeł. E. Balcerek, Warszawa 1992.

Hanus L., Princip pluralizmu, Bratislava 1997.

Heller M., Chrześcijański pozytywizm, [w:] tenże, Czy fizyka jest nauką humanistyczną?, Tarnów 1998.

Homiletická činnost cirkvív Slovenskej republike a jej dopad na kvalitu života v pluralitnej spoločnosti. Monografia k výsledkom vedecko-výskumného projektu VEGA č. 1/0070/08, ed. P. Procházka, Banská Bystrica 2010.

Hospodár M., Pastorálna teológia. Vseobecné zásady, tajomstvo krstu, Prešov 2013.

Hospodár M., Pastorálna teológia, vybrané kapitoly, Prešov 2010.

http://akcja.diecezja.bielsko.pl/bp-mariusz-leszczynski-xv-lecie-ak.

http://grkatba.sk/v-lutine-bol-vysvateny-pomocny-biskup-pre-presovsku-archieparchiu. http://wpolityce.pl/kosciol/225819-abp-depo-pod-haslami-pluralizmu-pogladow-tolerancji-

-zycia-publicznego-szerzy-sie-wielka-fala-rugowania-prawdy-i-wartosci-chrzescijanskich.

http://www.kul.pl/ks-prof-dr-hab-ryszard-kaminski,art_10320.html.

http://www.tkkbs.sk/view.php?cisloclanku=20090204017.

http://wyborcza.pl/1,75478,16848629,Prof_Jan_Wolenski_Kolejne_postulaty_Kosciola_

psuja.html\#ixzz3HkIe7Ah6.

http://zilina.sme.sk/c/4304594/dieceza-oslavi-prve-narodeniny-velkolepo.html\#ixzz3Na4P014a. 
Hułas M., Źródta sekularności. Analiza wybranych aspektów sekularyzacji, „Studia Nauk Teologicznych" 2014, Vol. 9.

Jakubowski W., Sztuka filmowa jako miejsce uczenia się, [w:] Kultura jako przestrzeń edukacyjna. Wspótczesne obszary uczenia się dorostych, red. W. Jakubowski, Kraków 2012.

Jarvis P., Osobowe uczenie się w dziataniu, [w:] Kultura jako przestrzeń edukacyjna. Wspótczesne obszary uczenia się dorostych, red. W. Jakubowski, Kraków 2012.

Kamiński R., Duszpasterstwo w spoteczeństwie pluralistycznym, Wrocław 1997, Teologia Praktyczna, 1.

Kardynał Claudio Hummnes (fragment wywiadu dla „Religion Digital”), [online] https:// dorzeczy.pl/swiat/15726/Wyrazili-watpliwosci-odnosnie-Amoris-laetitia-To-moze-doprowadzic-do-odebrania-im-kardynalatu.html.

Kasperek A., Teoria sekularyzacji i jej wrogowie. Próba apologii niepopularnej teorii, „Prace Naukowe Akademii im. Jana Długosza w Częstochowie. Seria Pedagogika” 2009, z. 18.

Kościót a pluralizm (debata redakcyjna), „Przegląd Powszechny” 1989, nr 7-8.

Kurczewska J., Trzy role Feliksa Grossa. Zaangażowany obserwator, ideolog, uczony, [w:] F. Gross, Wartości, nauka i świadectwa epoki, Warszawa 2002, Biblioteka Studiów Socjologicznych, 4.

Leszczyńska K., Strategie budowania wiarygodności Kościota rzymskokatolickiego w Polsce w obliczu transformacji kulturowo-politycznej po 1989 roku, „Studia Humanistyczne AGH” 2010, Vol. 8 .

Leszczyński M., Akcja Katolicka świadkiem Chrystusa w epoce sekularyzacji, referat wygłoszony podczas sympozjum z okazji 15-lecia Akcji Katolickiej diecezji bielsko-żywieckiej, Bielsko-Biała, 10 IX 2011, [online] http://akcja.diecezja.bielsko.pl/ bp-mariusz-leszczynski-xv-lecie-ak.

Lewowicki T., Polityka - spoteczeństwo - edukacja. O skomplikowanych uwarunkowaniach edukacji międzykulturowej, [w:] Polityka spoteczna i oświatowa a edukacja międzykulturowa, red. T. Lewowicki, E. Ogrodzka-Mazur, Cieszyn-Warszawa 2005.

Mach Z., Ksztattowanie rozumienia pluralizmu kulturowego w edukacji zjednoczonej Europy, [w:] Europa Środkowa - nowy wymiar dziedzictwa, 1991-2001, red. J. Purchla, Kraków 2002.

Mad'arová A., Cirkev a pluralitná spoločnost'v SR, „Evanjelikálny teologický časopis” 2010, nr 2.

Malewski M., Od nauczania do uczenia się. O paradygmatycznej zmianie w andragogice, Wroclaw 2010.

Mariański J., Kościót instytucjonalny w Polsce - szanse i zagrożenia, [w:] Katolicyzm polski na przetomie wieków. Teologiczny, instytucjonalny i wspólnotowy wymiar Kościota, red. J. Baniak, Poznań 2002.

Mariański J., Kościót katolicki a rozwój spoteczeństwa obywatelskiego, „Rocznik Lubuski” 2003, t. 24, cz. 1.

Mariański J., Kościót katolicki w spoteczeństwie obywatelskim. Refleksje socjologiczne, Lublin 1998. Mariański J., Kościót w spoteczeństwie przemystowym, Warszawa 1983.

Mariański J., Mtodzież między tradycją i ponowoczesnością. Wartości moralne w świadomości maturzystów, Lublin 1995.

Mariański J., Religia i Kościót w spoteczeństwie pluralistycznym. Polska lat dziewięćdziesiątych, Lublin 1993.

Mariański J., Religia w spoteczeństwie ponowoczesnym. Studium socjologiczne, Warszawa 2010. 
Mariański J., Sekularyzacja - desekularyzacja - nowa duchowość, „Przegląd Religioznawczy” 2012, nr 2 (244).

Mariański J., Sekularyzacja i desekularyzacja w nowoczesnym świecie, Lublin 2006.

Marrou H.I., Historia wychowania w starożytności, przeł. S. Łoś, Warszawa 1969, [w:] Humanizm i edukacja humanistyczna. Wybór tekstów, red. B. Suchodolski, I. Wojnar, Warszawa 1988.

Masarik A. (ed.), Homiletická činnost' cirkvi a kvalita súčasného života. Zbornik prednášok z vedeckej teologickej konferencie, Banská Bystrica 2009.

Mazurkiewicz P., Kościót i demokracja, Warszawa 2001.

Muszyński M., Edukacja i uczenie się - wokót pojęć, „Rocznik Andragogiczny” 2014, Vol. 21, [online] https://doi.org/10.12775/ra.2014.004.

Nikitorowicz J., Od podmiotowości do międzykulturowości i z powrotem. Próba interpretacji niektórych perspektyw teoretycznych, [w:] Wposzukiwaniu teorii przydatnych w badaniach międzykulturowych, red. T. Lewowicki, E. Ogrodzka-Mazur, Cieszyn 2001.

Nikitorowicz J., Pogranicze, tożsamość, edukacja międzykulturowa, Białystok 2001.

Ogrodzka-Mazur E., Edukacja międzykulturowa wobec problemów wspótczesności, „Gentes \& Nationes. Studia z Zakresu Spraw Międzynarodowych” 2012, nr 2.

Pasieka A., Hierarchy and Pluralism. Living Religious Difference in Catholic Poland, New York 2015.

Pasieka A., How pluralism becomes hierarchical? Debating pluralism in contemporary Poland, „Sprawy Narodowościowe. Seria Nowa” 2013, nr 43, [online] https://doi.org/10.11649/ sn.2013.018.

Petrík L'., Homiletická činnost v Gréckokatolickej cirkvi na Slovensku, „Theologos: teologická revue" 2013, nr 1.

Petrík L'., Viera je z počuvania a oblasovania. Homiletická interpretácia, Prešov 2013.

Piwowarski W., Pluralizm spoteczno-kulturowy a religia, „Roczniki Nauk Społecznych” 1980, R. 8.

Pluralizm światopoglądowy nie oznacza relatywizmu (lk/br, Warszawa, $20 \mathrm{~V}$ 2015), [online] http://ekai.pl/wydarzenia/polska/x89264/pluralizm-swiatopogladowy-nie-oznacza-rela tywizmu.

Popper K.R., Epistemologia a uprzemystowienie, [w:] tenże, Mit schematu pojęciowego. Wobronie nauki i racjonalności, przeł. B. Chwedeńczuk, Warszawa 1997.

Popper K.R., Tolerancja $i$ intelektualna odpowiedzialność (skradzione od Ksenofanesa i Woltera), [w:] tenże, W poszukiwaniu lepszego świata. Wyktady i rozprawy z trzydziestu lat, przeł. A. Malinowski, Warszawa 1997.

Popper K.R., Utopia a przemoc, [w:] tenże, Droga do wiedzy. Domysty i refutacje, przeł. S. Amsterdamski, Warszawa 1999, Biblioteka Wspótczesnych Filozofów.

Popper K.R., W co wierzy Zachód? (skradzione od autora Społeczeństwa otwartego), [w:] K.R. Popper, W poszukiwaniu lepszego świata. Wyktady i rozprawy z trzydziestu lat, przeł. A. Malinowski, Warszawa 1997.

Prymas Belgii: zaakceptować zsekularyzowane spoteczeństwo (Radio Watykańskie, 13 XI 2016), [online] http://gosc.pl/doc/3550432.Prymas-Belgii-zaakceptowac-zsekularyzowane-spole czenstwo. 
Przybylska E., Kultury uczenia się. Kilka refleksji w kontekście uczenia sięprzez cate życie, „Rocznik Andragogiczny" 2014, Vol.21, s. 119-131, [online] https://doi.org/10.12775/ra.2014.008.

Rowiński T., Sekularyzacja arcybiskupstwa brukselskiego (10 XI 2015), [online] http://christianitas.org/news/sekularyzacja-arcybiskupstwa-brukselskiego.

Różańska A., Edukacja religijna mtodzieży w warunkach pluralizmu religijnego w wybranych krajach Europy Środkowo-Wschodniej (Grupa Wyszehradzka: Polska, Czechy, Stowacja, Wegry) - studium porównawcze, Toruń 2015, Edukacja Międzykulturowa.

Różańska A., Ksztattowanie się tożsamości religijnej mtodzieży w sytuacji pluralizmu kulturowego i religijnego, [w:] Socjalizacja i ksztattowanie się tożsamości - problemy i sugestie rozwiąań, red. T. Lewowicki, B. Grabowska, A. Różańska, Toruń 2008.

Sadowski A., Edukacja międzykulturowa jako nabywanie kompetencji do życia w spoteczeństwie pluralistycznym, [w:] Edukacja międzykulturowa - teorie, poglądy, doświadczenia spoteczne, red. T. Lewowicki, E. Ogrodzka-Mazur, Cieszyn-Warszawa-Toruń 2010.

Scheler M., O idei cztowieka, przeł. A. Węgrzecki, [w:] M. Scheler, Pisma z antropologii filozoficznej i teorii wiedzy, przeł. S. Czerniak, A. Węgrzecki, Warszawa 1987, Biblioteka Klasyków Filozofii.

Schipperges K.-J., Religia a zeświecczone spoteczeństwo. Instrumentalizacja religii w nowożytnych systemach wtadzy politycznej, przeł. B. Floriańczyk, „Communio” 2003, nr 6.

Slavkovský A., The holy and dirty money offaith shapes of religion in contemporary society, „Spirituality Studies” 2015, nr 1 (1).

Słotwińska H., Pedagogika religii wobec pluralizmu religijnego, „Roczniki Teologiczne” T. 41, 2014, z. 11.

Stowacja i Polska - najbogatsze dziedzictwo tradycji katolickiej, „Wiadomości KAI”, Biuletyn Katolickiej Agencji Informacyjnej, Warszawa, 24 VI 2007, nr 25.

Sobecki M., Komunikacja międzykulturowa w wymiarze religijnym jako wyzwanie edukacyjne, [w:] Od wielokulturowości miejsca do międzykulturowości relacji spotecznych. Wspótczesne strategie kreowania przestrzeni życia jednostki, red. J. Nikitorowicz, J. Muszyńska, B. Boćwińska-Kiluk, Warszawa 2014.

Solarczyk-Ambrozik E., Ksztatcenie ustawiczne w perspektywie globalnej i lokalnej. Między wymogami rynku a indywidualnymi strategiami edukacyjnymi, Poznań 2004, Psychologia i Pedagogika - Uniwersytet im. Adama Mickiewicza w Poznaniu, nr 119.

Solarczyk-Ambrozik E., Oświata dorostych w zmieniającej się rzeczywistości - między nowoczesnościa a postmodernizmem, „Chowanna” 2005, nr 2.

Štefaňak O., Religia, moralność i polityka w opinii maturzystów stowackich, [w:] Narodowe czy wspólnotowe? W poszukiwaniu europejskich wartości, red. D. Gizicka, Lublin 2012.

Šturák P., 45 rokov od obnovenia činnosti Gréckokatolickej cirkvi v Československu, [w:] Gréckokatolicka cirkev na Slovensku vo svetle výroči III, Prešov 2013.

Šturák P., Dejiny Gréckokatolickej cirkvi v Československu v rokoch 1945-1989, Prešov 2008.

Šturák P., Historický prierez dejinami Gréckokatolickej cirkvi na Slovensku od počiatku ažpo súčasnost', [w:] Mariánske svätyne pol'sko-slovenského pohraničia; zbornik z konferencie projektu, Prešov 2013.

Šturák P., Prierez dejinami Gréckokatolickej cirkvi na Slovensku, Prešov 2002. 
Szahaj A., Wielość, względność, obojętność? O sekularyzacji i roli religii w debacie publicznej, [w:]

Nadzieje i zagrożenia sekularyzacji, red. C. Korc, R. Misiak, Szczecin 2010, Studia i Rozprawy - Wydziat Teologiczny Uniwersytetu Szczecinskiego, nr 26.

Szostek A., Prawda a zasada pluralizmu $w$ dialogu spotecznym i organizacji państwa, „Ethos” 1992, Vol. 5, nr 18/19.

Szostek A., Prawda i dialog: między relatywizmem a pluralizmem, „Ethos” 1997, Vol. 10, nr 37.

Śliwerski B., Diagnoza uspotecznienia publicznego szkolnictwa III RP w gorsecie centralizmu, Kraków 2013.

Śliz A., Szczepański M.S., Wielokulturowość i jej socjologiczny sens. Festival Caravan czy wielokulturowe Street Party?, „Studia Socjologiczne” 2011, nr 4 (203).

Świątkiewicz W., Tradycja i wybór. Socjologiczne studium religijności na Górnym Ślasku, Katowice-Wrocław 1997.

Taylor Ch., Świecka epoka. Dlaczego porzucamy religię, „Dziennik” 2007, 8 XII (dodatek „Tygodnik Idei. Europa”, nr 49 (192).

Tomko J., Cirkev a pluralitná spoločnost', [w:] Cirkev a pluralitná spoločnost.' Zbornik zo sympózia pri priležitosti 1. výročia zriadenia Žilinskej diecézy, ed. Z. Pupík, Žilina 2009.

Truchlińska B., Dialog i poróżnienie, „Sztuka i Filozofia” 1993, nr 7.

Vasil' C. SJ, Gréckokatolíci a jezuiti, [online] http://sk.radiovaticana.va/news/2013/06/16/vysielanie_pre_gr\%C3\%A9ckokatol\%C3\%ADkov:_gr\%C3\%A9ckokatol\%C3\%ADci_a_jezuiti/slo-702068.

Vasil' C. SJ, Gréckokatolíci. Dejiny - osudy - osobnosti, Košice 2000.

Vasil' C. SJ, Homília na biskupskej vysviacke Milana L'acha (1 VI 2013, L'utina), [w:] tenże, Bez súcitu vitazi nenávist.' Vybrane kázne arcibiskupa, Bratilsava 2016.

Vasil' C., Krestan by mal byt'brdinom, [w:] J. Majchrák, M. Hanus, Rozhovor s arcibiskupom Cyrilom Vasilom o rodine, utečencoch, pápežovi aj neduhoch v cirkvi, Bratilsava 2016.

Vasil' C. SJ, Na vlnách rádia Vatikán, Košice 2010.

Wielecki K., Podmiotowość w dobie kryzysu postindustrializmu. Między indywidualizmem a kolektywizmem, Warszawa 2003.

Wielokulturowość i pluralizm są bogactwem, nie zagrożeniem (kg/ju., Kraków, 7 IX 2009), [online] http://ekai.pl/wydarzenia/polska/x22252/wielokulturowosc-i-pluralizm-sa-bogactwemnie-zagrozeniem.

Witkowski L., Edukacja i humanistyka. Nowe konteksty humanistyczne dla nowoczesnych nauczycieli, Warszawa 2000.

Wojewoda M., Pluralizm aksjologiczny i jego implikacje we wspótczesnej filozofii religii, Katowice 2010, Prace Naukowe Uniwersytetu Ślaskiego w Katowicach, nr 2787.

Woleński J., Aksjologia i metodologia, [w:] Etyka zawodowa ludzi nauki, red. J. Goćkowski, K. Pigoń, Wrocław-Warszawa-Kraków 1991.

Woleński J., Racjonalizm niejedno ma imię, „Filozofuj” 2016, nr 3 (9).

Wolność jest piękna, o ile będzie bazować na wartościach. Rozmowa z prof. M. Novakiem, amerykańskim politologiem i myślicielem chrześcijańskim, „Wiadomości KAI”, 12 VIII 2007, nr 32.

Zenderowski R., Nad Tatrami btyska się.. Stowacka tożsamośc narodowa w dyskursie politycznym w Republice Stowackiej (1989-2004), Warszawa 2007.

Zenderowski R., Od tożsamości etnicznej ku tożsamości międzynarodowej. Stowacka tożsamość 
w perspektywie dyskursu politycznego (1989-2004), [w:] Państwo - spoteczeństwo - religia we wspótczesnej Europie, red. M. Mróz, T. Dębowski, Toruń 2009.

Zenderowski R., Religia a stowacka tożsamość narodowa, „Przegląd Zachodni” 2010, nr 1.

Zielińska K., Spory wokót teorii sekularyzacji, Kraków 2009.

Marek REMBIERZ - doktor habilitowany, pracownik naukowo-dydaktyczny Uniwersytetu Śląskiego w Katowicach, Wydział Etnologii i Nauk o Edukacji, Instytut Etnologii i Antropologii Kulturowej. Współredaktor tomów, m.in.: Bezradność. Interdyscyplinarne studium zjawiska w kontekście zmiany spotecznej i edukacyjnej (Katowice 2005, wraz z Zenonem Gajdzicą), Filozofia edukacji i etos rodziny (Bielsko-Biała 2007, wraz z Wiesławem Wójcikiem), Wokót „Pamięci i tożsamości” (Poznań 2010, wraz z Adamem Olechem), Rozum i wiara - intelektualne i duchowe dziedzictwo Jana Kantego (Kęty 2010, wraz ze Stanisławem Cadrem), Spoteczeństwo - kultura - moralność (Bielsko-Biała 2008, wraz z Zlaticą Plašienkovą). Wspólnie z Krzysztofem Ślezińskim zainicjował i redaguje (od 2006 roku) czasopismo naukowe (rocznik) „Studia z Filozofii Polskiej” (w 2015 roku ukazał się tom 10). Członek towarzystw naukowych, m.in.: Polskiego Towarzystwa Filozoficznego (członek Zarządu Głównego), Komisji PAN ds. Stosunków Polsko-Czeskich i Polsko-Słowackich (Oddział PAN w Katowicach), Stowarzyszenia Wspierania Edukacji Międzykulturowej, Polskiego Towarzystwa Pedagogicznego. 